Historic, Archive Document

Do not assume content reflects current scientific knowledge, policies, or practices. 

AIDINES

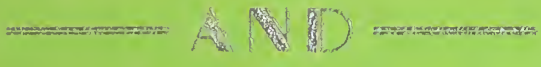

ROSES

Japunese lnises

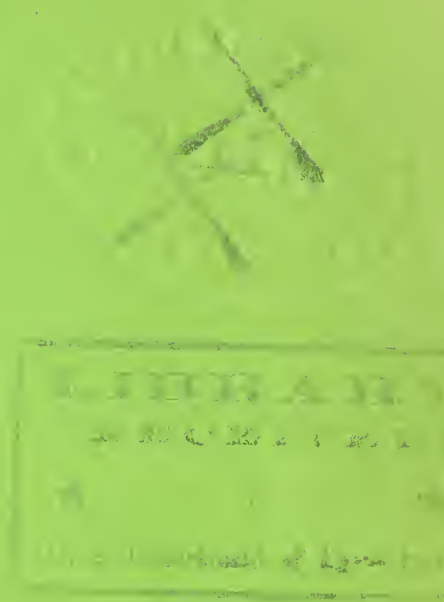

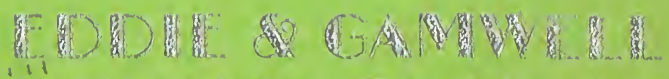

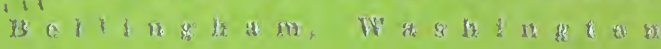





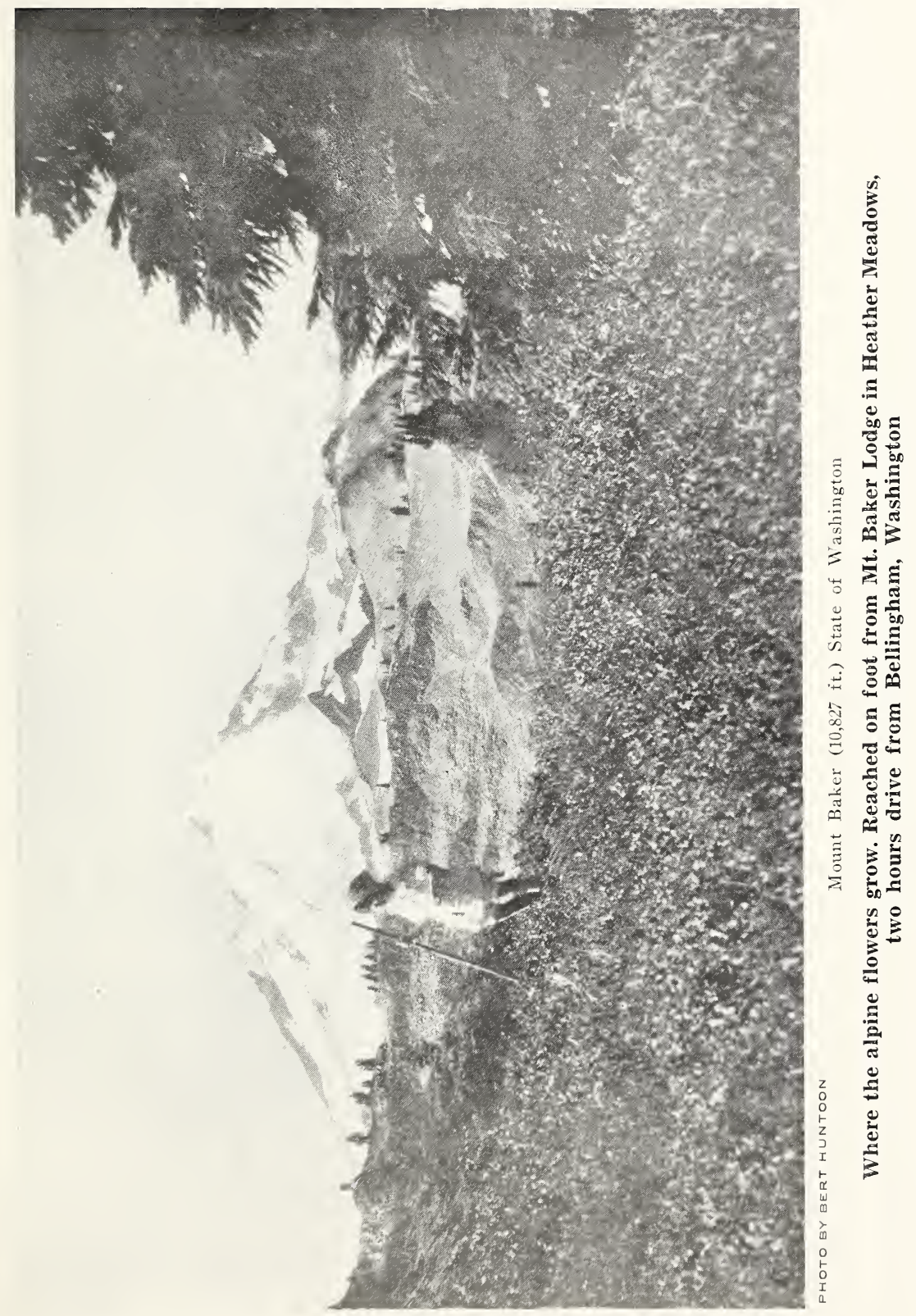




\section{ALPINE GARDENS}

Delightful miniature beauty spots made with rocks, water and plants associated in happy harmony may be created in any city garden and give a pleasing sense of intimacy with nature that seems attainable in no other way in the limited area uscally available under such circumstances.

A rock garden that will hold a hundred plants requires no more room than do the stars and circles and square "beds" which are annually "set out" to gaudy geraniums and flamboyant zinnias, perishable at the first frost and requiring costly renewal as the next season approaches.

The tiny alpines and other rockery plants, vines and shrubs are lovely at all seasons and, by judicious choosing, afford charming dainty contrasts of color and greenery all the year around.

In preparing this catalogue we have endeavored to present a list of the best rockery plants in cultivation at the present day, one that will please the most fastidious of gardeners as well as the beginner.

From the Swiss Alps and the Spanish Pyrenees, the loft Himalayas and far-away Andes-from our own American peaks and ranges are brought the dainty denizens of the mountainside, that their lavish beauty may make glad the garden of the city man and the country estate. Under experienced care they are trained to garden environment and taught to live under garden conditions.

Cur plants are field-grown, hence are hardy and able to stand the shock of transplanting and transportation. Every possible care is taken to send the plants correctly named and any error is, as far as possible, promptly rectified.

\section{EDDIE \& GAMWELL, Inc.}

Field Grown Roses

ALPINES

Japanese Irises, and Lilies

BELLINGHAM, WASHINGTON 


\section{A L P I NES Prices of Plants}

A dozen plants of the same kind will be sold at ten times the single plant price. For example, plants priced at $25 \mathrm{c}$ each will be $\$ 2.50$ per dozen. Special prices on larger lots. Three plants at dozen rate.

ACAENA Glauca-Unexcelled for carpeting, dwarf, spring flowering, evergreen foliage of bluish hue

ACHILLEA-Suitable for dry and sunny places in poor soil.

Argentea-Silvery foliage; white flowers on 4-inch stems

Tomentosa-Finely cut foliage; golden-yellow flowers on 6 to 12-inch stems

AETHIONEMA-Resembles Iberis, or Hardy Candytuft. Sub-shrubby in habit; foliage of most of them a beautiful glaucous blue. When planted in a light sandy or rocky soil, on dry sunny slopes, they will last for years. May to July.

Coridifolium-Rosy lilac flowers, 4 to 6 inches

Grandiflorum-Erect habit, rosy pink flowers on 12-inch stems........... $\quad .50$

Ovalifolium-Small and compact, 6 inches; light pink flowers.................... $\quad .30$

Persicum-Grey-green foliage, flowers deep rose. Very neat and compact

Schistosum-Of dwarf habit, rose flowers

AJUGA Reptans Rubra-Forms a close carpet of richly bronzed purple leaves. Blue Mint-like flowers on 4 to 6 -inch stems. For shady damp places

ALYSSUM-Invaluable for rockwork and edging. Requires a sunny position and well-drained soil.

Argenteum-Foliage silvery beneath. Large panicles of yellow flowers in clustered heads all Summer; 12 to 15 inches

Idaeum-A treasure for the rock garden, quite prostrate, with silvergreen leaves and soft, yellow blooms.

Montanum-Prostrate habit. Silvery leaves and fragrant yellow flowers; 4 inches

Repens-A very drought resistant creeper. Yellow flowers; 4 inches....

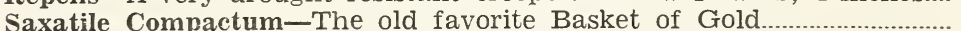

Saxatile Luteum-Sulphur yellow flowers.

Ptilotrichum Spinosum-One of the very best for the rockery. Woodystemmed, dense spiny, silvery foliage and very small numerous white flowers during June and July; 4 to 6 inches. Rare

Ptilotrichum Spinosum Roseum-A choice, rose-colored form............ $\mathbf{5 0}$

Wulfenianum-Resembles A. Montanum, flowers being paler yollow.... $\quad .35$ 
ANCHUSA-

Myosotidiflora-Of dwarf habit; bright biue Forget-me-not-like flowers on 12-inch stems. Prefers shade. May and June.

ANDROSACE (Rock Jasmine) - Requires a very gritty soil, the stones furnishing the cool moisture the roots enjoy. Not suitable for sticky clay nor hot, loose sand. Seem to prefer north aspect of rockery.

Laggeri-Small rosettes of dark green foliage, very compact. Umbels of bright pink flowers on short stems, May and June. Rare

Lanuginosa Leichtlini-One of the most beautiful and floriferous, blooming from June to October. Trailing habit and soft silvery foliage. White flowers with central eye of rose or crimson.......

Sarmentosa "Primuloides"-Rosettes of silky foliage and heads of rosy lilac flowers on 4-inch stems. May to July

ANEMONE SPECIES-Lovely, graceful subjects for the rockery, in most cases delighting in deep, rich soil in full sun.

Fulgens-Vivid scarlet flowers on 12-inch stems, April to June. A much sought for plant

Magellanica-White Strawberry flowers, and pretty, deeply cut foliage; 8 to 10 -inch stems. May to September

Montanum-Of the Pulsatilla type, but with nodding flowers of blue

Pratensis-Large dark purple flowers on 6-inch stems. New and rare....

Pulsatilla (Pasque Flower)-Large nodding flowers of violet-purple, filled with golden stamens. Seed heads are also very attractive; 8 to 12 inches. April to June

Rivularis-Robust Himalayan species with handsome heads of white flowers with bluish reverse, during summer months; 12 to 18 inches. Excellent for woodland planting

St. Bavo-New race of starry Windflowers. Colors range from scarlet through pink to lilac, blue and white, all with a silvery white center. March to June; 12 inches

St. Brigid (Irish Anemone)-Flowers in mixture of blue, pink, red and white. April to June. Plants in late Fall and early Spring.

St. Brigid Corms, or Bulbs-Early Fall; per dozen 50c; each

Sylvestris-Fine for a cool corner. Large white nodding flowers on 8 to 12-inch stems, May to July. Fragrant

ANEMONE HUPEHENSIS-A Chinese variant of the well-known A. Japonica, being somewhat more dwarf in growth, and flowering from early August until October. Rosy mauve; 12 to 18 inches..

ANTHEMIS Kelwayi-Finely cut foliage, golden yellow flowers. Blooms all summer in the poorest of soils.

Montanum-Valuable for its fine silvery grey foliage. White flowers

AQUILEGIA (Columbine)-Handsome foliage at all seasons of the year. Prefers light shade and a loose sandy soil, but will do very well in full sun and almost any kind of soil.

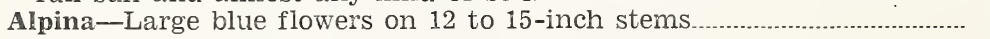

Chrysantha-Long-spurred yellow flowers ..................................................

Helenae-Large glaucous green leaves and flowers of pure blue, with pure white centers. Rather dwarf habit, 10 to 12 inches high................

Mrs. Scott Elliott's Hybrids-Long-spurred flowers in a wonderful mixture of colors 
Pyraneica-The most dwarf of all Aquilegia, making compact clumps of bright green foliage; dark blue flowers on 6 to 8 -inch stems from June to August. Rare and choice.

Glandulosa Jucunda-A marvelous beauty of powder-blue and white. Flowers 3 to 4 inches across, on 18 to 24 -inch stems. Prefers a rich soil and dislikes transplanting when flowering size has been reached.

ARABIS Alpina Compacta-Gray-green foliage, pure white flowers on 6 to 8-inch stems; April to June. Best in full sun

Alpina Flore Pleno--Double flowering form of the preceding. Makes an excellent cut flower to go with Primula, Heuchera, Viola, etc.

Alpina Variegata-Foliage edged with yellow. A bright spot in your rockery 12 months of the year. Best in rather poor soil.......................

Kellerii-New dwarf Rock Cress, very compact tufts of somewhat silvery foliage; 2 to 3 inches. Very choice

Muralis Rosea-Large dark green foliage. Rose pink flowers in racemes on 12-inch stems

Sturii-Cushions of glossy, dark green foliage; large heads of white blossoms on 2 to 4 -inch stems.

ARCTOSTAPHYLOS Uva-Ursi (Kinnikinic or Bearberry) - Prostrate evergreen shrub, white flowers, followed by red berries. Valuable for covering dry rocky or sandy banks, etc.

ARENARIA Balearica-Carpeting plant with dark green foliage, studded with countless white Fairy Stars. For a ccol, shady place, especially clothing bare rocks

Montana-Of trailing habit, forming mounds 4 to 6 inches high, covered with large white blossoms from April to July. For dry soils........

Purpurescens-Light lavender form

ARMERIA Caespitosa-Diminutive tufts of dark green spiny leaves, studded with almost stemless heads of lark pink flowers. Very rare

Caespitosa Hybrids-Hybrids of the preceding, somewhat more robust and having larger flower heads on stems 3 to 4 inches high, ranging from pure white to rose pink. Mixture only. New and rare..

Maritima-Compact tufts of grassy foliage. Pink flowers on 6 to 10inch stems

Vulgaris-The best Armeria for edging or border work, as well as for the rockery. Small, compact tufts of evergreen foliage, with heads of bright pink flowers on 6-inch stems from June to August.

ASCLEPIAS Tuberosa (Rutterfly Silkweed)-Large heads of brilliant orange flowers on 18 to 24-inch stems, from July to September. For hot, dry places

ASPERULA Cynanchica-A trailing plant with very fine foliage, making mats 12 to 18 inches across, covered from June to September with masses of pinkish flowers. Prefers very gritty soil 


\section{A S T E R S}

Acris-Choice species from Mt. Garibaldi, British Columbia

Alpinus Goliath-Large purplish flowers, with golden centers, on 12-inch stems. May and June

Amellus-A Southern European species of fine garden flower, preceding the Michaelmas Daisies proper in flowering. Rarely more than 2 feet in height, they form wide bushes smothered with large flowers.

Amellus King George-Very large deep blue flowers, July to September

Amellus Rudolph Goethe-Large lavender-blue flowers. August to Oct.

Farreri, "Big Bear"--Large flowers of the richest violet, with orange centers. Stock limited

Forrestii-Very large flowers of lavender-blue, with large golden centers, on stems 6 to 8 inches. Very new and rare.

Goliath-Large, beautiful lavender with intense yellow center.

Lichiangensis-Lovely Alpine Aster from China. Fine purple flowers on stems 8 to 12 inches. Requires a well-watered stony soil, mixed with peat and sand

Lipskyi-Large, well-formed flowers of brilliant lilac blue, with bright yellow center, on 12 to 18-inch stems. May to July.

Mauve Cushion-Hardy Japanese species, forming round, cushion-like plants, 2 to 3 feet across and 6 to 8 inches high, completely covered with mauve-colored flowers during October and November.

Pliades-Dainty foliage and branching habit. A real gem. Comes late when bloom is scarce.

Subcoeruleus, "Apollo"-An improvement on A. Alpinus. Immense blue or lavender-blue flowers, with a wide golden eye, carried on 10 to 15-inch stems, from May to July

Thompsonii Nana-About the daintiest little Michaelmas daisy for the rock garden. Very choice, from Mt. Garibaldi

Townsendi-Medium sized flowers of bluish-rose on 15 to 18-inch stems. October and November

Yunnanensis-A choice one from the interior of China. One of the best Blooms in July-August

Asters-Autumn type or Michaelmas daisies. We have a fine collection. If interested, ask for special list.

AUBRIETIA Hybrids-One of the most essential plants for rockeries or rock walls. At their best when placed to cover the face of a rock, or fall from a crevice of a rock wall. Also used extensively as cover for Tulip beds. Come in mixture of blue, lavender and pink shades

We can also supply the following select named varieties in nice plants at, each

Bridesmaid-Lovely, soft, delicate pink.

Gracae-Clear mauve, large flowers.

Lavender Queen-Like Gracae, but deeper color.

Crimson King-A real rich crimson.

Lissadell Pink-Deep pink, large blooms.

Doctor Mules-Deep, dark purple.

Rose Beauty-Deep, dark rose.

Leitchlini-Bright pink.

Moerheimii-Greyish foliage and large, soft, pearly-pink flowers. These named varieties are grown from cuttings and hence are true to name. Seedlings, while good, are not sure to come true. 
AURiCUla (Alpine Primrose)—See Primula.

BELLIS Perennis (Double English Daisy) - In separate colors of white, pink and red. Per dozen, $\$ 1.50$

Rotundifolia Caerulescens-A dainty little plant with pale lilac flowers on 3-inch stems. A very persistent blooiner from early May to late November. Requires a warm site

Minutum-Smallest dainty daisy imaginable, constant bloomer and a good comparison for the lovely Viola Bosniaca

CALAMINTHA Alpina-Makes a spreading mat like a large creeping Thyme, spangled with lavender-blue flowers from August to $\mathrm{S} \in \mathrm{p}$ tember, 6 inches

CALANDRINIA Umbellata-Makes a neat, slightly spreading tuft, with large glowing crimson flowers on 3 to 6 -inch stems from June to September. Full exposure to sun and light sandy soil are its only requirements

CALCEOLARIA Polyrrhiza-A dwarf species from Patagonia, of spreading habit. Dark yellow, purple spotted flowers on 4-inch stems, June to August

CALTHA (the Latin name for Iarigold)-This is a genus of beautiful marsh plants. Fine for the edge of a pool, but succeed admirably well in an ordinary border in rather rich soil. They generally mature two crops of bloom in the same season.

Caltha Leptosepala-Native of Washington. Lovely waxen bloom, with yellow center

Caltha palustris-The large yellow "Marsh Marigold".

Caltha uniflora-Native of Oregon, with large shiny leaves and white, buttercup-like flowers on 10-inch stems.

CAMPANULA (Bellilowers) - The taller varieties are suitable for the perennial border and valuable as cut flowers, while the dwarf sorts are dell adapted for edging and rock work. With a few exceptions prefer a rich, sandy loam, and will last much longer in bloom if planted in a half-shady place. We are listing some of the very rare varieties this season, such as Allioni, Arvatica, Fragilis, Fenestrellata, Pulla, Piperi (true), Raineri and Saxifraga.

\section{ALPINE VARIETIES:}

Allioni-One of the very best of the Campanula. Large, lilac-colored flowers, the largest for the size of the plant of any of the Campanula, studding the ground on inch-high stems. Is of spreading habit. Requires very gritty soil, the stones furnishing the cooling material the roots require; 2 to 3 inches

Arvatica (Acutangula) - Dwarf, with training stems, somewhat like C. Garganica, from a rosette of Ivy-like leaves. Covered in June and July with lovely large and star-like purple-blue flowers. Also requires very gritty soil. Best in moraine; 2 to 3 inches

Aucheri-Large, rich, purple bells on 3-inch stems. Very choice and rare

Barbata-This is the bearded Bellflower of the high Alpine meadows, combining beautifully with Hiericum or the late-blooming Alyssums 
Carpatica-Large, saucer-shaped flowers of blue on 6 to 12-inch stems, above the campact mass of green foliage. June to October... .25

Carpatica Alba-White flowering form of preceding

Carpatica Isabel-Choice china-blue saucer on lovely hairy stems and foliage.

Carpatica Riversiea Beauty-One of the loveliest. Very large, deep violet blue. Comes late

Collina-Lovely species from the high ranges of the Caucasus. Foothigh stems with graceful, purple bells.

Elantines-A dainty little prostrate, pale blue, white-eyed species, with downy foliage

Excisa-A very choice and rare Alpine. Mats of grassy foliage, small pale blue flowers on slender 2 to 3 -inch stems. Likes a cool, moist air, and not too full exposure to the sun.

Fenestrellata-A Croatian form near C. Garganica, with smooth, shiny foliage. Covered with pale blue star-like flowers, June to August; 4 inches

Fragilis-This is one of the best (C. Isophylla and Mayii being the others) species for hanging baskets and window boxes, and for covering large stones in the rockery. Also for dry-rock wall work. Trailing stems often 18 inches in length, covered with large, pale purplish-blue flowers, $1 \frac{1}{2}$ inches across, from August to October..

Garganica-Compact rosettes of shiny foliage. Trailing stems covered with light-blue star-shaped flowers, which have small white eye, all summer

G. W. H. Paine--Larger blooms and more spreading tufts. Very choice

G. Hirsuta-Lovely, grey hairy foliage. Rare and good. A striking plant

Glomerata Acaulis-Large clusters of rich violet flowers on 2 to 3 -inch stems, May to July. This is not the common Glomerata, 20 to 30 inches high, but a very dwarf form

Glomerata Nana-Cluster bells of deep purple

Hallii-Dainty white, resembling the white C. Pusilla.

Isophylla-Invaluable for window boxes, hanging baskets, dry rock walls and for covering large stones in the rockery. Pure white flowers 1 inch across

Isophylla Mayii-Blue flowering form of the preceding

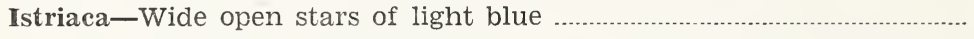

Laurii-Resembles C. Rotundifolia in habit, but with the lovely lavender bells turned up instead of drooping; 8 to 10 inches; May to July

Muralis Portenschlagiana-Dense, dwarf tufts of dark green foliage, covered with blue-purple bell-shaped flowers on 3 to 6 -inch stems from June to November, a very long flowering period. Excellent for dry, rock walls.

Muralis Bavarica-Improved form of the preceding, with larger flowers

Olympus-Native of the Olympics. Size of flowers is double that of old type of C. Rotundifolia. Also more compact growing and very drought resistant. Long flowering period, May to November. Rare $\mathbf{1 . 0 0}$

Piperi-A rare species found only in the Olympic Mountains of Washington. Distinctive, shining Holly-like evergreen foliage, $3 / 4-$ inch long, forming charming rosettes. A dainty open, bright blue flower with protruding stamen of intense scarlet which brushes off with the slightest handling. Sold only with orders of $\$ 5.00$ or more 
Pseudo-Rainerii-Hybrid between C. C. Rainerii and Turbinta. Salver shaped leaves and lovely purple bells

Pulla-Makes a very dense mat of fine foliage. Shining bells of deepest purple-blue, or russet-purple, on 2 to 3 -inch stems. Requires very gritty soil. June to August

Pusilla-Strong grower, making large, dense mats of fine foliage, with

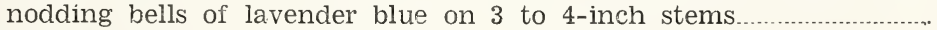

Pusilla Alba-White flowering form of preceding.

Raddeana-A treasure from the Alps of Transcaucasia. Round, glossy leaves, sharply toothed at the edge. Branching sprays of large violet bells on 9 to 12 -inch stems. June to August

Rainerii-One of the choicest of Alpines from the Italian mountains by Lake Como. The greyish foliage forms mats only about an inch high. China blue flowers, nearly as large as those of C. Carpatica on 2 -inch stems. North or east exposure, in well drained but moist soil

Rotundifolia, C. M. Hark (Bluebells of Scotland)-Slender branching stems with dainty blue flowers. June to September; 12 inches............

Standsfieldi-Choice creeper of rare charm, deep purple bells................

Steveni Nana-Beautiful little mat-forming species, appreciating a cool, moist place

Saxirraga-Tufted narrow foliage. Large deep blue or purple-blue flowers on 4 to 6 -inch stems. Very choice and rare. Very gritty soil. June to July

Tommasiniana-Diminutive, choice wee campanula from the Italian Appenines. Narrow, blue flowers on slender stems. Plant forms a dense tuft and likes partial shade

Zoysii-One of the choicest moraine campanulas from a limestone scree. Lavender-blue

CAMPANULA-Border varieties. Of these we have a large list of named varieties in good, strong field-grown clumps. If interested, please ask for list.

CARYOPTERIS Mastacanthus Nainus (Blue Sipirea)-Invaluable for potting, border or rockery. Shrubby perennial with greyish foliage and lavender,-blue flowers the whole length of its 10 to 18-inch branches. Prefers a well-drained and sandy soil in a sunny location. Cut back severely each season; 2 feet. September to November.

CATANANCHE Coerulea-Heads of pretty deep blue flowers on slender 18 to 24-inch stems from June to August. Often used as everlastings. Any soil

CEANOTHUS Prostratus-One of Oregon's best shrubs for the rockery. Makes creeping mats of evergreen Holly-like foliage, covered in the Spring with umbels of dainty Lilac-flowers; 2 to 3 feet across........

CENTAUREA Montana (Perennial Cornflower)-Large violet-blue flowers on 12 to 18-inch stems from July to September. Any soil, full sun....

Montana Alba-White flowering form of preceding.

Pulcherrima (Aetheopappus Pulcherrima)-Bushy plant, 18 to 24 inches high, bearing a profusion of rose-pink Cornflowers, from June to end of August. Finely cut and very handsome foliage

CERASTIUM Tomentosum (Snow-in-Summer)-Strong growing creeper for very poor soils. Masses of silvery foliage with snow-white flowers on 6-inch stems. May and June 
CHEIRANTHUS Allioni (Siberian Wallflower) - A flare of dazzling orange flowers on foot-high stems. For poor, dry soils

Kewensis-A hybrid with multi-colored flowers, pale primrose passing to orange-yellow and violet. Flowers very fragrant on erect stems 18 inches high. Early Spring to Winter

Linifolius-New dwarf species for dry rock walls and borders. Lilacmauve flowers on 6 to 8 -inch stems. June to August

CISTUS (Rock Rose)-A wonderful shrub for the dry rockery or wall.

Laurifolius-Compact bushes about $3 \mathrm{ft}$. high, covered with large, pure white flowers during July and August. Sandy soil in full sun. Each

$50 \mathrm{c}$ and

Villosus-Rather dwarf, 12 to 18 inches high. Leaves and young stems shaggy with whitish hair. Large flowers of rose, yellow at base

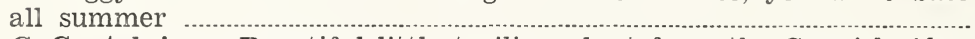

C. Cantabricus-Beautiful little trailing plant from the Spanish Alps.

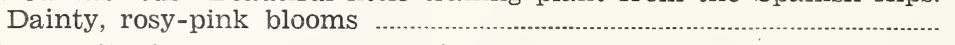

C. Mauritanicus-One of the finest and most persistent Summer-blooming plants for rockery or border. Requires a well-drained spot and some protection, as it comes from Africa. Blue flowers from June to November. While a trailer, it is not a spreader

CORYDALIS. Fumitory-Ornamental, early flowering plants, especially useful for half shady positions. Requires drainage. Family notable for beautiful foliage, usually blue green.

Cheilanthifolia-Fern-like foliage and long spikes of yellow flowers, May to July. Requires a rich, well-drained, stony soil, and does well in shade; 10 to 15 inches

Thalictrifolia-One of the best recent introductions from China. Bright, clear yellow flowers in long racemes. Handsome plant............

COTONEASTER-Essential creeping shrubs for the rockery.

C. Adpressa-Dwarf pressed against the ground or rocks. Lovely glossy leaves turning red in Autumn. Bright red berries. Attractive...

C. Humifusa-Perfectly prostrate, evergreen, with slender creeping stems. Large solitary white flowers and good-sized berries of coral red

Cortula Squalida-Tiny, fern-like foliage. Splendid for stepping stones or in the angle of steps

COTYLEDON Simplicifolius-Low tuffets of Sedum-like growths with gracefully arched 8 to 10 -inch stems of small golden flowers, during June and July. Requires partial shade in well-drained soil ...............

CRUCIANELLA Stylosa-Masses of dainty green foliage, with clustered heads of rosy-pink flowers from May to July. For a rough, sunny corner

CYCLAMEN Hederaefolium-This Alpine cyclamen is very rare. Has brilliant carmine blossoms and showy leaves beautifully marbled with white. Semi-shade

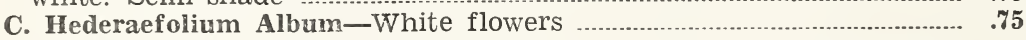

CYPRIPEDIUIM-Hardy Orchids that thrive in a moist, peaty soil in shade or half-shade. Odd shaped flowers with uncommon colors and markings. May and June.

Acaule (Moccasin Flower) - Two large leaves, flat on the ground. Solitary pink-purple flowers on 8 to 10 -inch stems 
Each

Montanum-Native of Oregon. Brown and white flowers on 12-inch stems

Pubescens-The yellow Lady's Slipper. Rather large yellow flowers on 10 to 15 -inch stems

Spectabilis-The Showy Lady's Slipper. The finest of the genus. Large rose-purple or white flowers on 12 to 18 -inch stems..

CYTISUS-Tiny dwarf brooms. Choice for the rockery.

Dalmatica-Quaint little gorse of rare charm

Kewensis-Lovely cream colored prostrate ................................................ 1.25

Nigricans-Splendid, late blooming plant. Grows 2 to 3 feet, but fine for correct location

Purpureus-Graceful, arching sprays of deep lavender in May. Choice type

Pilosa-The daintiest of rock garden brooms, tiny foliage and quaint wee blossoms. A real treasure

Radiata-Choice little genista with silvery foliage

Saggittalis-A dwarf prostrate broom. Stems curiously winged like an arrow. Yellow flowers in terminal, short racemes. Large plants..

DAPHNE Cneorum-The Rock Daphne. Handsome evergreen foliage and crowded heads of fragrant, bright pink flowers during May and June. Rather dwarf, 8 to 12 inches high, but often 18 to 24 inches across. Sun or shade. One year old, 75c; large clumps, $\$ 1.50$ to...

Mezereum-Makes a shrub, deciduous, from 2 to 4 feet high. The fragrant, lilac-purple flowers, silky outside, appear long before the foliage. February to April. Stock limited

Odora-The sweetest of all fragrant flowering shrubs. Glossy evergreen foliage, slightly variegated, yellow-edged. Clusters of light pink, waxy flowers early in the Spring. Small plants, \$1.00; large specimens

DELPHINIUIMS-Tiny ones for the rock garden.

Cashmeriana-From the highlands of Tibet

Pylzowii-From Kansu, China. Dainty violet blue ……........................ 1.00

Tatsiense-Another Chinese variety of quaint azure color. Graceful.... 1.00

Nudicaule-Native along mountain streams in Northern California. Brilliant scarlet flowers on 12 to 18 -inch stems.

DIANTHUS (Alpine Varieties) - Indispensable for dry, sunny places or walls and with very few exceptions great lime lovers. Like a poor stony soil, but care should be exercised that soil is not too loose or sandy. While they require a well-drained soil, if too loose or sandy there is a tendency for roots of small plants burning during the hot days of midsummer. A dressing of small stone chips in Fall is beneficial.

Allwoodi-Alpinus-A new perpetual flowering hybrid. Large flowers of bright pink shades on 6 to 10 -inch stems. Loam with some lime. Summer

Alpestris-Little fringed pink blooms

Alpinus-Very dwarf. Deep rose-pink blooms as large as a quarter....

Alpinus Alba-White flowering form of preceding

Alpinus Carmineus-This is an especially fine carmine bloom, with 
a deeper carmine eye

Arenarius-Blush lilac fringed flowers.

Arvenensis-A wonderful carpeting variety. Spreading mats of greygreen, covered with small, sweet pink flowers from May to July; 2 to 3 inches

Brevicaulis-Close mats of rose-mauve flowers. Tight mats of toothed leaves. A gem

Callizonus-The choicest of Alpine pinks. A treasure among treasures, large flowers in the form of Alpinus, lighter pink, spotted white. Very rare. Sold only with orders in excess of $\$ 5.00$..

Crinitus-One of the daintiest little ones. Soft, fringy white blossoms

Deltoides-Great trailing mats of glossy green; small pink blossoms speckled with crimson, on 6 to 8 -inch stems. May to July.

Deltoides Baikalii-A gem from the shores of Lake Baikal in Siberia. Larger flowers and more brilliant pink than any other deltoid type. Recent introduction

Freynii-Bluish-grey cushions upon which appear to sit the daintiest little pink blossoms. Lovely thing for the moraine.

Glacialis-Very compact tufts of dark, glossy foliage with large rosecolored flowers on 1 to 2-inch stems. Gritty sand and peat, with a little shade during hot Summer

Graniticus-Taller growing than Deltoides, with large rose-colored flowers. Full sun and gritty soil.

Haematocalyx-A grey foliaged specimen of great beauty, ample blossom of purplish pink

Hungaricus-Dwarf little mottled pinks. New.

Inodorus-Small Grassy tufts; bright salmon pink flowers on 2 to 4-inch stems during June and July. Very rare.

Kamtchaticus-Of trailing habit, with large bluish-pink flowers from June to September

Knappi-An excellent plant for high in the rockery, or the top of rock wall, in order that foliage and flowers may be kept clean. Of straggling growth, with large heads of clear yellow flowers from June to August. The only yellow Dianthus known; 12 to 18 inches..

Microplepsis-Another grey foliaged one. Attractive plant. Lovely carmine heads of bloom

Napoleon III-Rich, ruby red. An indescribably beautiful dianthus. The most gorgeous coloring imaginable

Neglectus-The most beautiful of all Alpine Pinks in cultivation. Neat little grassy tufts, studded with bright pink flowers, with a buff reverse, on 6-inch stems. Poor, stony soil. June and again in Sept....

Plumarius Hybrids-Many colors, fragrant, good.

Sundermanni-Pure white flowers with the fragrance of Jasmine, particularly noticeable at night. New and rare

Squarrosus-Dainty white feathery pinks

Subacanlio-Very dwarf, tufted variety with delightful little pink blossoms

Superbus-Grassy foliage, large fringed flowers of white, 8 to 12 inches 
DIANTHUS-Border varieties. We have a fine collection of these hardy carnations. Invaluable for cutting in every garden. Named varieties. Good clumps

DICENTRA Eximia (Plumy Bleeding Heart)-Dwarf growing variety, finely cut foliage and showy racemes of rose-pink flowers throughout a long blooming period, April to July. Does equally well in either full sun or shade, its only requirement being a well-drained position; 10 to 12 inches

Spectabilis-The old favorite Bleeding Heart. Heart-shaped flowers of rose-crimson, in long drooping racemes. May and June

DOUGLASIA Laevigata-The Olympic Mountains form. Glossy dark green foliage, in neat, compact tufts. Bright pink flowers on 2 to 3 -inch stems in early spring. Very rare

DOUGLASIA Vitaliana-Often known as Androsace Vitaliana. Rosettes of grey-green foliage with small sprays of clear yellow flowers. Sweet scented; 1 inch

DRABA Aizoides-Forms beautiful little rosettes of seemingly prickly foliage, covered in eariy spring with bright yellow flowers on 2inch stems

DRYAS Octopetala-One of the most charming of all dwarf shrubs for the rock garden; flat evergreen carpets of very small Oak-like leaves with medium-sized white Anemone-like flowers during Spring and Summer. It flowers most freely in very limy soil. Also likes soil which is well drained, porous and a sunny but not dry position. Flowers are followed by silvery fluffy whirls of seeds. Resents being disturbed

DRYAS Sundermanni--A hybrid of preceding with larger flowers, which are pale yellow in the bud stage, opening white. Same conditions as preceding

EDELWEISS-See Leontopodium.

EDRAIANTHUS-See Wahlenbergia.

EPIMEDIUM (Berberidaceae)--This genus contains some of the daintiest and most interesting plants that can be grown in the rockery.

Niveum-Snow-white flowers, beautiful heart-shaped foliage.

Sulphureum-Pale yellow flowers, bronzy foliage.

EPILOBIUM Hectori-A neat creeper; as leaves age, they have the appearance of hammered copper. Small white flowers. Less than 1 inch high

ERICA (Heather) - The Heaths are compact, low-growing shrubs and very useful for rock work. Either full sun or half-shade, in lime-free soil.

Carnea Rosea-Without question one of the finest rocizery shrubs to be had. Very low-growing, forming wide-spreading mats, which disappear in Winter and early spring under masses of ruddy-red bells. Plant in open, porous soil, with a little sand and peat moss, 50c to $\mathbf{1 . 0 0}$

Daboecia Polifolia (Irish Bell-Heather)-Evergreen bushes of 8 to 18 inches, with terminal racemes of large inflated, reddish-purple or white bells, from June to November. Sandy peat is the best medium for growing them 
ERIGERON-Showy plants with daisy-like blooms. Very effective used in masses.

Alpinus-Compact tufts of dark green foliage, with small delicate pink flowers on 3 to 4 -inch stems, from May to July...

Aurantiacus-Close tufts of dark green foliage with bright orange flowers on 8 to 12 -inch stems, June to August. Full sun in dry location

Caucasicus-Of dwarf habit, with heads of lavender flowers on 8-inch stems

Compositus-Daintiest little Alpine daisy, a treasure in the rock garden

Mucronatus-An everblooming variety. Trailer, with dark green foliage and small pink and white daisy-like flowers. One of the most persistent bloomers in our gardens during the hot, dry Summer months

Multiradiatus Roseus-A fine pink-flowering variety, 12 to 15 in.; June

Pumilus-A trifle larger than Compositus. Good.

Speciosum-We consider this one of the finest plants for the foreground in the herbaceous border. Large, rosy-mauve flowers, with yellow centers, on 18-inch stems, during June and July. As cut flowers, will last for 6 to 10 days

Trifidus-A pretty native. Flattened tufts of little hairy, hand-shaped leaves and delicate daisy-like flowers of pale lavender on 2 to 3inch stems. A persistent bloomer. May to August

ERINUS Alpinus-Charming little evergreen wall and crevice plant, forming pretty little dark green carpets, with a profusion of rosy-purple flowers on 4-inch stems, during May and June

Roseus-A bright pink flowering form of the preceding. New

ERIOGONUM Umbellatum-A native low-growing woody shrub, with small evergreen leaves. Fluffy balls of small yellow flowers on 6 to 8-inch stems during the Summer. Dry, sunny position................

ERIOPHYLLUM Caespitosum (Oregon Sunshine)-A native with finely cut grey foliage and a profusion of yellow daisy-like flowers on 12inch stems, from June to August. For the poorest of soils, in a hot, dry position

ERODIUM-Valued in the rock garden for their steady succession of bloom during the summer. They enjoy dry, sunny spots.

Amanum-Grey-green, delicate foliage with ample white blossoms. A choice thing

Cheilanthifolia-Beautiful grey foliage. Flowers white with purple blotch

Chrysanthum-Similar foliage, but with dainty yellow blossoms ........ $\mathbf{. 7 5}$

Maoradeum-Much like above, with blush pink flowers...................... $\quad .75$

Manescavi-From the Pyrenees. The well-known "Heron's Bill." Rosy purple flowers

ERYNGIUM Bourgati-A very distinct species. Dwarf, spiny stems and bracts, often a bright steel blue. Flower heads blue, rarely green; 12 inches. June to August

Planum (Sea Holly) - Used as an everlasting. Holly-like leaves and Thistle-like heads of deep blue flowers, 3 to $4 \mathrm{ft}$. July and August.... 
ERYTHRAEA Diffusa Massoni-Belongs to the Gentian family, and often called the Pink Gentian. Of trailing habit, with neat, evergreen foliage and small pink flowers during July and August. Prefers a light soil, in full sun or light shade; 3 to 5 inches

EUONYMUS Radicans Variegata-These trailing Euonymus, with their small green and white variegated leaves, are taking the place of English Ivy for wall coveroing. Also make splendid ground cover and one of the best creepers for the rockery or rock wall.......50c and

EUPHORBIA Cyparissias (Cypress Spurge)-Like a miniature Cypress, with many yellow flower-like bracts during May and June; 10 in.

FELICIA Petiolata Rosea-A desirable trailing plant for a rock wall, hanging down from 2 to 4 feet. Small pink daisy-like flowers throughout the Summer. Needs a little protection where temperature drops much below freezing

FERNS-Dwarf Rock Ferns-Shade is not essential for these Ferns, although Pellaea Densa appreciates a little of it. They will live with very little moisture after June has passed by.

Cheilanthes Gracillima (Lace Fern)-Four-inch leaves, woolly beneath, on 4-inch brown stalks

Pellaea Brachypteris-A tiny fern for the rockery for full sun.

Pellaea Densa (Cliff Brake) - Another tiny Fern, best with some shade

FRAGARIA (Creeping Strawberry)-A very rapid grower, for covering rocks and steep banks. Has a small red berry

GENTIANA-The Gentians furnish the rock and bog gardens with some of their most glorious subjects. While some are rather difficult, there are some comparatively easy and all will repay any effort made to give them conditions to their liking. The Alpine varieties in general are singular in requiring an extremely large amount of root moisture, combined with good drainage. One difficult problem is to keep plants as cool as they are in their mountain homes without shading them more than nature does. Planting on north or east side of a well-submerged stone, so that roots of plant may have the cooling effect of it, is one answer. Medium sized stones may also be placed at the bottom of hole in which plant is placed, so that roots may come in contact with them. Nearly all enjoy peat mixed with their soil.

Acaulis-The famous Gentian of the Swiss Alps. Huge, dazzling Gentian blue trumpets, covering a dwarf green carpet. Variable as to time of flowering here, for while their regular time is early Spring, many flowers may be seen from November onward.

Andrewsii-The Closed Gentian. Terminal heads of large blue flowers, on 12 to 18 -inch stems. Somewhat of a bog plant, enjoying moist soil and shade. July to October

Calycosa-Oregon's most beautiful Gentian and one of the most beautiful of all Gentians. Many flowering stems crowned with large Gentian blue flowers from July to October. It likes a moist soil, abundant in leaf mold, and while collected plants are rather hard to get established, our nursery-grown-from-seed plants have a fine root system and may be moved with safety; 8 to 12 inch. Small plants $75 \mathrm{c}$; large 
Clusii-A form of G. Acaulis, with flowers somewhat longer and a darker shade of blue. Leaves are a little longer. Likes a little lime 1.25

Cruciata-Another lime-lover, with full sun preferred. Not as showy as some but easy of cultivation. Terminal and axillary clusters of blue flowers on 10 to 15 -inch stems from July to September.

Dahurica-Large leaves and flopping stems, carrying large umbels of deepest blue

Farreri-Pronounced by many to be the most beautiful of Gentians. Of semi-prostrate growth and grassy foliage. When once established, it will produce hundreds of its glorious flowers of a wonderful shade of sky-blue, with white throats. Of vigorous habit and will bloom from August to time of frost

Lagodechiana-A dwarf form of G. Septemfida, with large flowers of pale blue, being somewhat variable in color. Semi-prostrate habit and enjoys full sun. July to September.

Linearis-Another bog native of the Eastern States. From 3 to 5 blue flowers on 12 to 18-inch stem. Excellent for shady places. July to September

Menziesii-A dwarf native, with small blue flowers on 6 to 8-inch stems, semi-prostrate

Pneumonanthe-The English heath Gentian. Slender stems with clusters of lovely blue-purple bells in Autumn

Septemfida-Of easy culture. Heads of sapphire blue flowers, somewhat variable, on 8 to 12 -inch stems, during July and August........

Sceptrum-From Washington bogs. Flowers clustered, blue usually, dark blue spots within

Sino-Ornata-Considered by many the most beautiful and glorious of all Gentians. Habit somewhat like G. Farreri, with immense dark blue flowers, with a white line running through the divisions.

Requires lime-free soil, being somewhat of a lime-hater; 6 inches. August to November. Small, \$1.00; large

Verna-Lovely spring Gentian. Bright blue stars with white center. April-May. From the European Caucasus. Rare

Walujewii-A strong grower with large leaves and clustered heads of pale blue flowers during late Summer. Shade required.

GERANIUM Ibericum-A fine species for the herbaceous border, thriving in any good garden soil. Violet blue flowers on 12 to 18-inch stems from June to August. If planted in sunny position, foliage assumes rich tints in Autumn

\section{GERANIUM:}

Argenteum-This is a delicate little gem. Silver-grey foliage with apple-blossom pink blooms. Retains its color best in half shade.... $\mathbf{1 . 0 0}$

Traversi-Lovely grey-green foliage with clear pink blooms.................. .75

Sanguineum (Lancastriense)-Low-growing, prostrate type with pale pink blossoms

Sanguineum Roseum-Rich, rose-shade of the above ........................ .75

Plyzowianum-A dainty little sprite from North Tibet. Nodding pink flowers

Wallichianum-Prostrate, trailing habit. Stems and leaves covered with silky hairs. Blue-veined purple flowers. From the Himalayas.... 1.00 
GEUM, Alpine or Evergreen Varieties-These are doubly valuable for the rock garden on account of their handsome evergreen foliage and large showy flowers, which are produced from early spring to late Fall. Like full sun, with plenty of root moisture, in a deep, rich soil. Seed heads also very attractive.

Borisii-One of, if not the finest, of this showy genus. Neat tufts of evergreen foliage with many branching 8 to 12 -inch stems, covered with large, vivid orange-scarlet flowers from May to October. Root divisions

Bulgaricum-Dark green foliage, with orange-yellow or tangerine flowers on 8-inch stems. Rare

Heldreichii-A dwarf species from Greece, with orange-red flowers on 8 to 12 -inch stems. June to August

Heldreichii Hybrids-Grown from seeds gathered in our gardens, probably hybrids between Bulgaricum and Heldreichii. Very large flowers of orange-red or scarlet on 10 to 12 -inch stems. A valuable addition to this already showy family. Stock limited

Kolbianum-A variation of $G$. Heldreichii, somewhat taller, with lighter colored foliage. Deep orange-red flowers.

Montanum-Prettily puckered, glossy green leaves and large bright golden flowers on 3-inch stems, off and on all Summer. Stock very limited

Sibericum-Medium-sized flowers of coppery scarlet, on 8 to 12-inch stems. Very bright and telling

GLOBULARIA-Showy in the rockery, requiring well-drained soil and not too hot sun.

Cordifolia-Tiny prostrate sub-shrub covered in early summer with tiny, fluffy blue balls

Nana-Similar to above but more minute.

GYPSOPHILA_Lime-loving plants, bearing a profusion of small flowers giving a mist-like effect.

Cerastoides-From the Himalayas. Flowers white, veined purple,

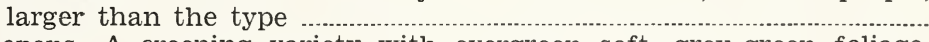

Repens-A creeping variety with evergreen soft, grey-green foliage, pinkish white flowers

Repens Rosea-Rose color form of above.

HELIANTHEMUM (Sun Rose)-Showy, small evergreen shrubs, suitable for planting on walls and dry banks. Their only requirements are a sandy soil and full sun. If cut back after flowering in early Summer, they will often flower again in the Fall. Should be cut back to keep them from becoming straggly. Named varieties grown from cuttings, guaranteed.

Apricot-Large Apricot colored flowers, glossy foliage....................... .50

Boule de Feu-A double flowering deep red ......................................

Burnt Orange-Glossy foliage, prostrate habit.......................................... $\quad .50$

Rodanthe Carneum-Silvery foliage, lark pink flowers ......................... .50

Speciosum-Orange and salmon, large-leafed and very fine

Tuberaria-Glossy, corrugated foliage, from which rise 6 to 8 -inch spikes of golden yellow flowers 
Vulgaris (Mutabile)-Plants grown from seed. Mixture of colors, white, pink, red, etc.

HELLEBORUS-Hardy, herbaceous plants, admired for their very early flowers, and also for their very attractive foliage. Will thrive in ordinary garden soil, but for best results use a soil of rich loam, coarse sand, some peat moss and a top dressing of well-rotted manure. Prefer a moist, but well-drained position, partially shaded during the hottest part of the Summer months. Shade of deciduous shrub or tree preferred. Resent being disturbed.

Praecox Niger-The Christmas Rose. In our mild Puget Sound climate commence to bloom during November and continue through the winter, regardless of snow and ice. Of rather dwarf habit, leaves and flower stems being from 6 to 8 inches high. Flowers open white, sometimes flushed with pink. Makes a good-sized flowering clump the second season. Two-year plants, $\$ 1.00$; large plants... 2.00

Orientalis, or Hybridus-(The Lenten Rose, so-called on account of its flowering period being during the time of Lent, February to April.) Erect growing, 12 to 18 inches, with very large divided leaves. Large flowers, 3 to 4 inches across, in white, pink, maroon, etc., many of them speckled red, brown or green. This species does not flower until the third season, and being of hybrid origin, it is impossible to tell color of flowers until plants are 3 years old. Two-

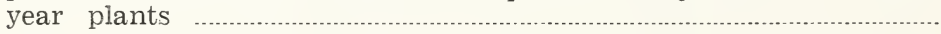

Pink, white and speckled, 3-year-plants ….................................... 1.50

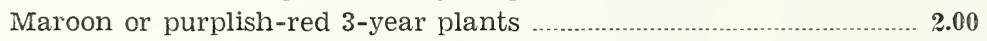

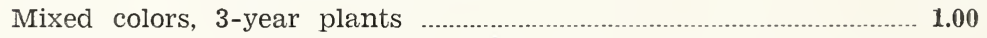

HELXINE Soleirolii-Very small bright green leaves, whole plant being less than $1 / 2$-inch high. Requires moderate shade

HEPATICA-Early Spring flowering plants, belonging to the Anemone group. Prefer a rich, well-drained loam in shade. In full sun flowers turn white instead of usual blue or pink. Should be left undisturbed.

Acutiloba-Pink or blue flowers on 4 to 6 -inch stems.

Triloba-Blue flowers on 4 to 6 -inch stems. Blunt leaves

HERNIARIA Glabra-One of the best hardy trailers for poor sandy soil. Makes a dense mass of mossy foliage, which turns to a deep bronzy red in winter. Comes from Western Asia

HEUCHERA-All the Heucheras are of very dainty habit. From a lowgrowing tuft of heart-shaped leaves spring a number of slender scapes, 10 to 15 inches tall, with delicate small flowers borne in panicles, giving a delightful, airy effect. The following varieties are all good:

Alba-Dainty white bells

Brizoides-Lovely shade of rose

Gracillima-Dainty, pink, semi-double …............................................... $\quad .50$

La Perie-A new red one.................................................................50

Pluie de Feu-Another one of fiery red ............................................ $\quad .50$

Rosmondi-Also new. Delightful shade of pale pink

Sanguinea ("Coral Bells")-Ranks among the half-dozen best rockery or border plants, with small, red flowers 
HORMINUM Pyrenaicum--Neat tufts of dark green foliage, which lies flat on the ground. Medium-sized flowers of violet-purple on 12 to 15 -inch stems

HOUSTONIA Coerulea (Bluets)-Compact tufts, with small flowers, varying from blue to white, on 4-inch stems, during early Spring. Prefer a moist, shady place, thereby prolonging flowering period and allowing plants to retain their foliage much longer than if planted in drier and sunny place.

HUTCHINSIA Auerswaldii-Dense rounded cushions of glossy emerald green, starred over with dainty white flowers from May to July. Prefers a shady, moist position

HYPERICUM-Dainty little under-shrubs, quite essential for a rock garden.

Coris-A very distinctive species, and the best for the rockery. Spreading glaucous, Heath-like foliage, with rather large yellow flowers; 8 to 10 inches. Very choice and rare

Fragile-A trailing variety with golden cups on the ends of lateral branches

Polyphyllum-Very desirable, dense little shrubby plants covered with large yellow cups all Summer

Repens-A splendid covering for a large rock in a sunny location........

IBERIS-Hardy Candytuft-_These almost evergreen sub-shrubs rank high in a rock garden collection. Their dark green leaves are almost completely covered with the flower clusters nearly all Summer.

Gibraltarica Hybrids-The most showy and striking perennial candytuft. Blossoms shade from deep lavender to white. Constant bloomer. Strong plants of blooming age

Pruitii-Semi-prostrate habit. Flowers white .........................................

Sempervirens-Leaves oblong and glabrous. Flowers white...

INCARVILLEA Delavayi-Large rich rose Gloxinia-like flowers on 24 to 30 -inch stems, June to August. The pinnate foliage is also very handsome

INULA Ensifolia-A very satisfactory plant for soil that is rather poor. Compact bushes, 12 to 16 inches high, with large yellow Daisylike flowers during July and August. Full sun

Royleana-New Himalaya species, with rich orange colored flowers, 4 to 6 inches across on 2 -foot stems. Large, handsome leaves and the black buds are very conspicuous. June to August

IRIS-The species and varieties listed below are considered to be the finest of the beautiful Iris natives of Oregon and Washington. They are nursery-grown and may be moved with safety, preferably durthe fall months. Being woodland plants they prefer semi-shade.

Bracteata-Slender dark green foliage, almost evergreen. Flowers deep yellow, veined with bluish-purple; 12 inches. May and June...

Chrysophylla-Grassy foliage and white or soft yellow flowers, tinted and veined lavender; 6 to 10 inches. June and July.

Gormanni-A rare species, dwarf, with slender foliage. Soft yellow flowers, from May to July, having the longest flowering period of any of the Iris; 6 to 10 inches 
Tenuis-A wide-leaved woodland Iris with white flowers, marked with yellow and purple. A beautiful rarity ..............................................50

We also list a few of the Eastern Natives, as follows:

IRIS Cristata-Fine blue flowers, 6 to 10 inches.

Fimbriata (Syn. Japonica) - Thick, smooth leaves, 12 to 18 inches long; flower stems as long as the leaves, slender with a raceme of lilac flowers with crimped margins, yellow on the claw, crested.

Prismatica-Native of the Northeastern States. Prefers wet conditions. Slender plant, leaves shorter than flower stem which is from 12 to 24 inches. Bright lilac, yellow on the throat, marked with purple and darker veins

Stylosa (Unguicularis)-The Winter blooming Iris. Large lavender blue flowers, on 6 to 12 -inch stems, sweetly scented. Should be grown in soil consisting of broken bricks and mortar rubble. 50c; large clumps

ISATIS Glauca-Stems 3 to 4 feet high, with big showers of minute

golden flowers in Summer. In effect almost a golden Gypsophila

JASIONE Perennis-Tufts of pretty green foliage, globular heads of bright blue flowers on 12-inch stems. June to August

JUNIPERUS-Communic Nana-Native dwarf Juniper. A high mountain creeper, with very dense and grey-green foliage. Delights in sandy or gravelly hillsides, fully exposed to the sun. Excellent ground cover and trims very well. Small plants only.

LAVENDULA Atro-Purpurea Nana (Dwarf French Lavender)-Very dwarf, 6 to 10 inches. Silvery-grey foliage with tiny spikes of rich purplish-blue flowers in dense heads. June to September.

Delphinensis-A rare and interesting species, with pale blue flowers on 12 to 18 -inch stems

LEONTOPODTUMI Alpinum (Edelweiss)-That much sought-for Alpine of the Swiss Alps. Grey leaves of small yellow flowers, which are surrounded by star-like heads of leaves, clothed with a woolly substance. Requires a well-cirained, stony soil .

LEWISIA-These rare and chcice Alpines come from the far Northwestern part of the United States and British Columbia. They are found growing in clefts of the rock in gritty soil, in weil-drained positions. They are perfectly hardy and, where nursery propagated, are readily adjusted to rock garden conditions. They are exceptionally vaiuable subjects.

Columbianum-Evergreen rosettes of rather narrow leaves, with smail pink and white striped flowers; 6 to 10 inches. June and July........

Columbianum Roseum-Flat rosettes of dark evergreen leaves, with masses of medium-sized rosy-purple flowers on 6 to 8-inch stems, from May to November. This species has the longest flowering period of any of the Lewisia. New.

Cotyledon-Evergreen rosettes of narrow, sharp-pointed leaves, not very dense, with white flowers which have many pink lines. June and July

Finchii-A beautiful species. Close rosettes of broad evergreen leaves,

1 inch wide and 3 to 4 inches long, flat on the ground. Flowers white or pale pink, with deeper stripe down the center of each petal, on 6 to 10 -inch stems 
Howelli-Lovely native of Oregon. Crinkled foliage with radiating head of apricot flowers, penciled with rose. One of the finest.............

Oppositifolia-A deciduous species. Long, narrow leaves in rosettes. Stems bearing from 1 to 5 pure white Aster-like flowers; 6 to 10 in.

Rediviva-Another deciduous species. Waxy white or pink Water Lily-like flowers, the size of a dollar, on 2 to 3 -inch stems, among the long needle leaves.

Tweedyi-This is the most beautiful of all! Found on the steep coast mountains of Washington. Attractive foliage and a glorious bloom of soft pink resembling a miniature waxen Water Lily

LINARIA-Essential subjects for the rock gardens and are of easy culture in ordinary soil and exposure.

Acquatriloba-The prettiest and most interesting of the genus. For rock work or lily ponds, walls and crevices of walks. Covers the earth with a green film spangled with violet flowers

Alpina-Compact habit, with spreading flower stems. Flowers blue or lavender, sometimes pink, with orange-scarlet palate. Off and on all Summer. Well-drained, sunny situation

LINUM Alpinum-One of the daintiest of the Blue Flax. Prostrate, not over 4 inches high, with large, clear sky-blue flowers all Summer...

Narbonnense, "Six Hills Variety"-Large sapphire blue flowers on 18inch stems. Flowers do not drop off each day, but last for several days. Plants are of dwarf, compact habit.

Perenne-The old favorite Blue Flax.

.25

Salsinoides-Pale mauve, penciled lavender ............................................... . .75

Salsinoides Nana-Quite prostrate................................................... 1.00

Viscosum-A dainty plant throwing up a large, single pink bloom. Good and late bloomer

LIPPIA Repens-A close-growing, rapid spreading ground cover for rocks, steep banks, or to hang over walls. Clover-like heads of delicate rose-colored flowers, on stems 2 to 3 inches high. Any kind of soil

LITHOSPERMUM Prostrate sub-shrubs. In density of growth and profusion of bloom few of the rambling shrubs can vie with them.

Froebeli-Flowers of very bright blue. New.

Gramnifolium-Dainty little shrub with pale blue blossoms diffused with pink

Petraem-Much like the above, but with longer foliage and deeper blue

Prostratum-Choice rock rover. The delight of a rock garden. Bright here from February to December with Gentian blue blossoms...........

Prostratum, Heavenly Blue-Like above but with large, sky-blue flow-

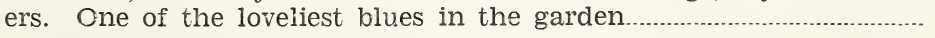

LOTUS Corniculatus-Lovely little rock cover for a partially shaded corner, with little pea-shaped flowers in early Summer

Corniculatus Flore Pleno-Double form of above. Rare.

LYCHNIS Alpina-Compact tufts of olive-green foliage; deep rose colored flowers on 4 -inch stems, June and July. Full sun 
Chalcedonica (Jerusalem Cross) - Heads of brilliant scarlet flowers on 2- to 3-foot stems. June to August...

Flos Cuculi (Ragged Robin) -Deep pink flowers on 12-inch stems. For very poor soils; full sun

Flos Jovis-Leaves covered in silvery flannel. Clusters of carmine pink flowers on woolly foot-high stems, all Summer. Very striking.

LYSIMACHIA Japonica-Bright yellow flowers, axillary, on 2-foot stems

Nummularia (Creeping Jenny)-Neat carpeting plant for shade or semi-shade, with large yellow flowers during July and August........

LYTHRUMI Salicaria-Thrives in any soil, but prefers wet, marshy situations. Large spikes of rosy-purple flowers on 2 to 4 -foot stems....

MALVASTRUM-Sub-shrub of easy culture.

Coccineum-Canescent stems with cut-leafed foliage and short racemes of brick-red or coppery flowers

MAZUS Rugosus-A dainty and interesting Alpine creeper for semi-shaded places. Covered during May and June with white and purple Lobelia-like flowers; 4 inches

MECONOPSIS-Interesting, poppy-flowered little herbs, giving choice bits of color to the rockery.

Baileyii-The choicest of all Blue Poppies

Cambrica (Welsh Poppy)-Large single flowers of orange-yellow on 12 -inch stems, April to June. Full sun

Pratii-Chinese species. Deep-blue Poppies

MERTENSIA Laevigata-A woodland native. Wonderful blue flowers, during May and June, on 2 to 3-foot steams. Unlike M. Virginica, it does not dy up and lose its foliage as soon as flowering period is past, but retains its green foliage until well into July...

Pulchella-One of the finest of our native blue flowers. Six to 8-inch stems, bearing a drooping cluster of deep blue flowers, sometimes tinted pink. Choice and rare

Virginica (Virginia Blue Bells) - Bluish-grey foliage and long arching racemes of rich sky-blue flowers on 2 to 3 -ft. stems, April to June

MIMULUS-Lovely subjects for the rockery, preferring moist, half-shady places.

Cardinalis--From moist places in the Umpqua Valley. Bright scarlet....

Langdorfii-A native of Washington. Creeping habit and yellow flowers

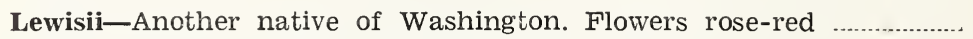

Lewisii Albus-A white variation of above. Rare

MYOSOTIS, Barr's Blue (Forget-Me-Nots) - Compact habit, with 8 to 12 inch flower stems. Per dozen, $\$ 1.50$

Palustris Grandiflora-The true perennial variety. Also called the Water Forget-me-not. Commences to bloom in June and continues throughout the Summer, provided growing in some shade and well watered. Stems 12 to 18 inches.

Rupicola-The Queen of Alpine Forget-me-nots. Small, compact tufts of dark green foliage, hidden by crowned heads of large flowers of deep blue. Choice and very rare. Stony soil in open position. 
NEPETA-Perennial herbs of easiest culture, valuable in the border and in the rockery.

Glechoma-A creeping Mint, making solid carpets. Steep banks.

Mussini-Silvery-grey foliage, with 8 to 12 -inch spikes of lavender-blue flowers from May to September. For hot, dry places. Aromatic............

Nuda-Resembles preceding, but of more upright habit, leaves more silvery and flowers more blue

Ukranica-NEW. Somewhat taller, 12 to 18 -inch spikes of dark blue flowers from June to September. Very satisfactory rock plant...

OENOTHERA Pusilla-Small glossy green tufts and short stems with small yellow flowers. For poor, dry soils. June and July

OMPHALODES Verna-A low-growing, rambling plant for very poor soils in shade. Large heart-shaped leaves and drifts of large blue Forget-me-not-like flowers on 4 to 6 -inch stems. February to May

Cappadocica-A handsome dwarf hardy herb from the Mediterranean. Large myosotis-like flowers of rarest blue. Enjoys a little shade

ONONIS-Sub-shrubs from the Mediterranean countries.

Cenesia-Dainty little apple-blossom pink peas on minute little shrub $\mathbf{1 . 0 0}$

Rotundifolia-Dwarf rock garden shrub, with pretty foliage and rosecolored Pea-shaped flowers. Requires a well-drained, sandy soil, in full sun; 12 inches. June and July

ONOSMA Tauricum-(Golden Drops)-Makes large, compact masses of rough, hairy foliage, 12 to 15 inches across. Clusters of soft yellow bells, wonderfully fragrant, on 15 to 20 -inch stems, from July to September. Should be placed well up in the rockery, or near the top of the wall, as they succeed best in full sun and a light, open, deep soil, and also for the reason that its true beauty is best seen then

ORNITHOGALUM Umbellatus (Star of Bethlehem)-Bulbous plant with dark green, grass-like foliage and 6 to 8 -inch stems with heads of from 12 to 20 flowers. May and June. Bulbs

Clumps, 3 to 4 bulbs

\section{OXALIS (Geraniaceae)-}

Adenophylla-A beautiful Chilean mountain plant, Profusion of greygreen leaves beneath dainty blooms of soft lilac-pink.

Enneaphylla-The glory of the Falkland Islands. Similar to above with waxy, white flowers

Floribunda Rosea-The old favorite. Umbels of rosy blooms all Summer long

Magellanica-Wee white flowered Oxalis of rarest charm

Martiana (incorrectly Maritima)-Same as Floribunda.

PACHYSANDRA Terminalis (Japanese Spurge)-Bright, glossy foliage, 8 to 10 inches high. Excellent ground cover for all shady places and the only other plant which will thrive under pine trees. Hardier than Ivy or and other dwarf shade-loving plant

PAPAVER Alpinum-Neat tufts of finely cut foliage and dainty flowers, often fringed, of white, rose, yellow or orange. Well-drained sandy soil. Mixture of colors only 
Coonara, Pink Strain-Iceland Poppies, a large percentage of which come in shades of pink, balance in yellow, orange and some white; 12 to 15 inches. Well-drained soil

Improved Sunbeam Strain of Iceland Poppies. Large flowers on 12 to 18-inch stems

Pilosum-Brick red flowers on 2-foot stems, May to July

Rupifragum-Flowers on 12 to 15 -inch stems resemble bits of orange silk. Likes hot, dry situations, and will bloom all Summer if not allowed to go to seed

PAROCHETUS:

Communis-Found in the Himalayas at elevations from 4,000 to 13,000 feet. Constant bloomer. Beautiful Pea-shaped azure flowers.

PENTSTEIMON-This American genus furnishes us with the finest material for rock and wall work. The requirements for their success are simple; a gritty or stony soil with sharp drainage and full sun. Amid the almost universal confusion of names in this family, it is difficult indeed to be sure of names. Insofar as possible, plants listed below have been identified by comparison with herbarium specimens named by National Museum Botanists, or by direct identification by them of specimens

Acuminatus-Grey foliage. Gentian blue

Acuminatus Albus-White flowered form of above.

Barbatus Torreyi-Rather tall for the rockery, but a graceful beauty for the border. Stems 2 to 3 feet tall set with thin, scarlet tubes from June to September. Excellent for cutting.

Barrettae-Choice native of Oregon. Silvered foliage and glorious lilac flowers

Cardwelli-Native evergreen shrub, 8 to 12 inches high, covered several times each season with short spikes of bright purple flowers....

Fruticosus-Native evergreen shrub, narrow, dark green foliage and lilac-lavender or blue flowers, June and July

Glaber (Speciosa) -A rather variable species. Blue-green foliage and crowded spikes of blue flowers, daintily tinted with pink; 10 to 12 inches

Heterophyllus-Neat evergreen shrubs, 10 to 12 inches high; the unopened flowers tingled with pink but upon opening a beautiful blue. Off and on all Summer

Menziesii-A Washington native evergreen creeper, with very small leaves; 4 to 6 -inch spikes of blue or purple flowers, June and July....

Newberryi-Dwarf native evergreen shrub, resembling P. Cardwellii, but with beautiful deep pink flowers; 6 to 8 inches. Very rare............

Procerus-Masses of Gentian-blue heads on very ample stems and lush foliage

Rattani Minor-Dwarf heads with blue-lavender flowers .....................

Rupicola-A rare and beautiful evergreen from rocky cliffs in Washington mountains, with greyish foliage and bright red flowers on 3 to 4-inch stems. Of very compact and dwarf habit, it is very drought resistant and one of the best Alpine shrubs for dry, rocky places

Scouleri-Native of Washington. Nearly evergreen here. Dwarf. Lovely spikes of violet-purple flowers in May and June 
Scouleri Albus-Choice white form of above. Very fine

Shirley Giant or Sensation-Gloxinea flowers of rose, crimson, lilac and light pink. Gives the border much color when it needs it. July to October. Two feet. Mixed colors 25c; separate colors

PERNETTXA Mucronata-A Heather-like shrub, with small bright green leaves and white flowers, followed by various colored berries, like large Huckleberries, which are edible. Requires an open, sandy soil, in full sun. Neat, compact specimens.

PHLOX-Alpine and Rock Garden Varieties-Our Western American Native Phlox take their place in the front ranks of the choicer Alpines and rock plants.

Adsurgens-Native evergreen trailer, and one of the finest of Oregon's natives. Bright green leaves, stems 3 to 6 inches high with large flowers of a salmony shade of pink. It likes full sun, but requires plenty of root moisture. A very rare gem for the rock garden. June to August

Amoena-Native of the Eastern States. Dwarf green foliage, covered, in early Spring with a sheet of pink, and again in the Fall; 4 inches

Diffusa-Native creeper, making mats of soft green foliage with large white, pink or lavender flowers all Summer

Divaricata Canadensis-Native of Middle Western States. Heads of lovely, fragrant lavender flowers on slender 12-inch stems from May to July. Enjoys semi-shade

Divaricata Laphami-Stronger growing and longer blooming than preceding, with large purplish flowers. Foliage also handsomer. Rare

Douglasii-Native creeper. Compact, prickly mats and bright pink to white flowers

Setacea Moerheimii-Resembles preceding, but more compact in habit, and with beautiful carmine-pink flowers

Setacea Vivid-Very dwarf and compact, with bright, fiery rose flowers. The best of the Setaceas

Stolonifera-Native of Eastern States. Evergreen creeper with rosepink flowers in Spring

Subulata (Moss Pink or Phlox) - Prickly evergreen foliage, covered in early Spring with pink, lavender or white flower's on 2 to 4 -inch stems. Very strong grower. State color desired.

\section{Named Varieties of Subulata Type:}

Frondosa-Vigorous, rose colored

G. F. Wilson-Soft lilac

Lilacina-Light mauve, deeper ring in center ..........................................

Nivalis-White flowers

Seraph-Dainty variety.

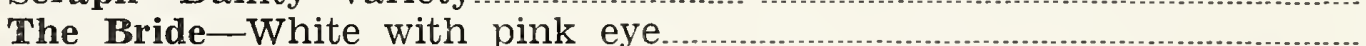

The Sprite-Soft lavender

Vivid-Beautiful bright rose. The best

PHYTEUMA Scheuchzeri-A rare rock-loving species, requiring full sun without damp, little soil and that of leaf mold and sand. Deep violet-blue flowers in rounded heads on slended stems, 6 to 10 inches high. May to July

Spicatum-A woodland species. Close spikes, 12 to 18 inches high, of blue flowers, rarely white, with greenish tips 
Each

PLUMBAGO Larpentae-Very desirable for many reasons; of dwarf spreading habit, 6 to 8 inches high; deep cobalt blue flowers in profusion during the late Summer and Fall, and for its Autumn tinted foliage during Fall months

POLEMONIUM:

Carneum-A native with fine foliage of fern leaves and graceful stems carrying the large flowers, varying from cream and flesh color to rich rose in fading; 8 to 12 inches. Long flowering period, June to September

Coeruleum-Glossy, ferny leaves and spikes, 18 to 24 inches high, of lovely blue flowers

Elegans-Flowers in dense cyme. Violet with broad yellow throat. From the almost inaccessible regions of the wildest part of the Olympic mountains of Washington. Very scarce. Sold only with order exceeding $\$ 5.00$

Humile-Low slender plant from creeping root stocks. Comes from about the limit of trees in the Washington mountains. Purplishblue flowers

Reptans-Larger than Humile. Umbels of bright blue florets....................

Pulcherrimum-Loveìy china-blue blossoms

POTENTILLA-Handsome foliage, free-blooming plants, showy blossoms which continue from Spring to Autumn. Easily cultivated, doing well in an open position.

Aurea-Quite dwarf with yellow flowers

Cinerea-Compact grower, large yellow flowers .......................................

Nitida-The choicest of the Alpine Potentillas. Silver-grey foliage, beautiful in itself, and the most gorgeous rose bloom.

Nepalensis Roxana-From the Himalayas. Very large flowers of brilliant salmon, with darker veins toward the base. The ripe anthers with yellow pollen look like golden ornaments on a velvet cushion. New and rare

Nepalensis Willmottae-A cherry-red flowering form of the preceding

Reptans-Excellent creeper for ground cover. Bright yellow flowers on 2 to 3 -inch stems all Summer

Tonguei-Dwarf, unique colored flowers of bright orange and terracotta

PRIMULA-A lovely and varied family from the high Alpine species, an inch or two high when in full bloom, to the giant, moisture-loving kinds displaying their bold flowers in tier upon tier on stems of 3 feet or more. Mostly strong-growing and often moisture-loving plants which, failing permanently moist positions, may be grown in partial shade with a little attention in watering. A good fibrous loam seems to suit all of them, with some well-decayed manure dug in 6 inches or more (manure should never come in contact with the crowns and leaves of these plants.)

Beesiana-Glowing velvety purple flowers.

Bullesiana Hybrids-iWide range of colors, orange, pink and purple shades, in whorls on stems 18 to 24 inches high. Not as difficult as some

Bulleyana-Whorls of flowers of a rich orange, shaded buff and apricot, on 18 to 24-inch stems. For shady, moist situation. 
Please send remittance with order. We do not solicit orders under $\$ 1.00$.

Packages will be sent with charges collect, either by express or parcels post, as you may specify.

This method is more satisfactory than attempting to quote postpaid prices, which, in many instances, must necessarily mean extremely small plants.

Six plants of a sort at the dozen rate; 50 of a sort at the hundred rate.

The greatest care is taken to supply stock true to name and effort is always made to satisfactorily adjust any error in this regard, but in accordance with the custom of the trade, no guarantee is given.

Make remittance to

EDDIE \& GAMWELL, Inc., Bellingham, Washington

If you have friends interested in gardening and are inclined to send their addresses, we shall be most appreciative.

\begin{tabular}{l|ll}
\hline \hline Name & Address & City or Town \\
\hline & \\
\hline & \\
\hline
\end{tabular}

Do you know the "Christmas Rose?" It is not a rose, but a lovely flower that comes in the last month of the year and, unless covered by icy Winter, will bloom until the snow-drops open. While not a real rose, its flowers are as beautiful as small, single white roses. It scorns winter protection anywhere.

If you will order something else, we will send you a good clump for $\$ 1.00$.

EDDIE \& GAMWELL, Inc.,

Bellingham, Washington 


\section{ORDER BLANK EDDIE \& GAMWELL. Inc. \\ BELLINGHAM, WASHINGTON}

Date.

Name.

(Please Print or Write Name Plainly)

Street or Rural Address.

City

State

Remitiance enclosed, \$

If unable to send every item ordered, shall we substitute?

How do you wish shipment made:

Parcels post.

Express.

When do you wish shipment made?

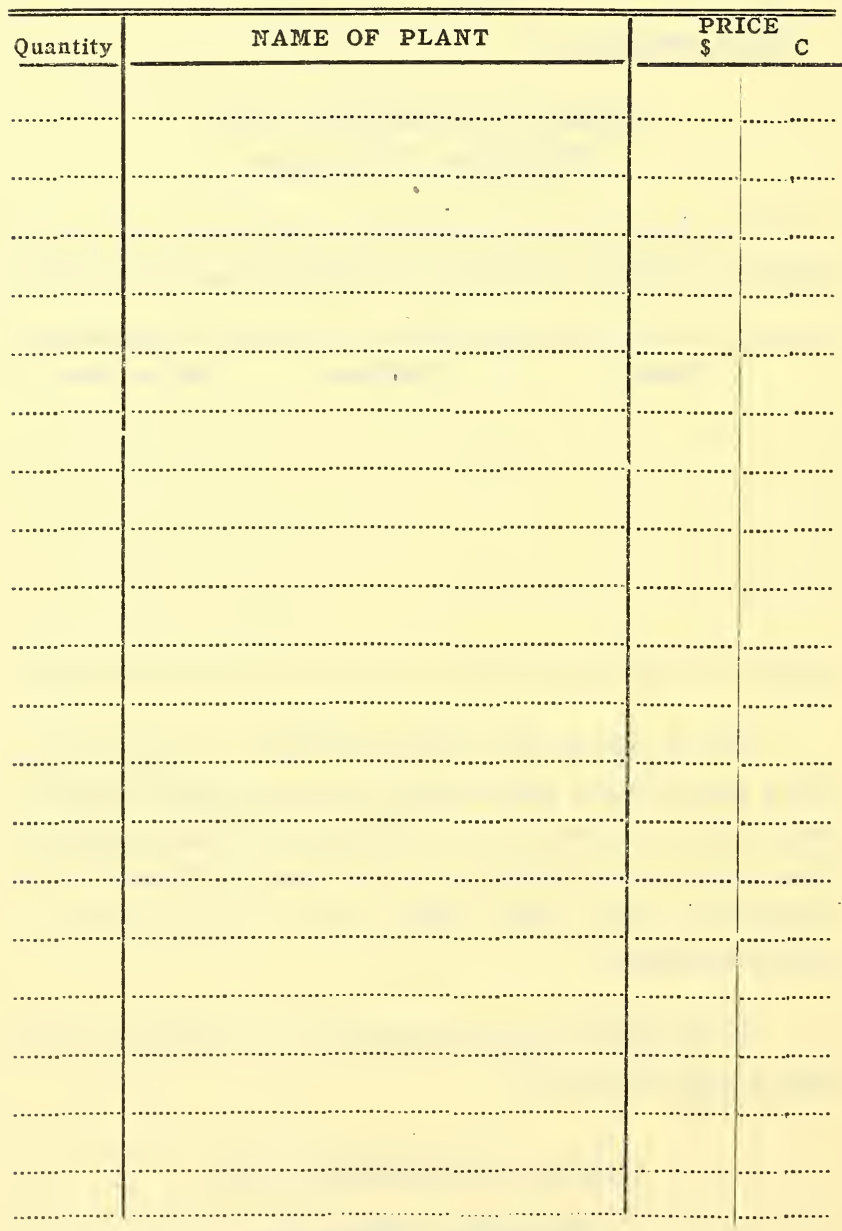




\section{ORDER BLANK \\ EDDIE \& GAMWELL, Inc. \\ BELLINGHAM, WASHINGTON}

Date

Name

(Please Print or Write Name Plainly)

Street or Rural Address.

City

State

Remittance enclosed, \$

If unable to send every item ordered,

shall we substitute?

How do you wish shipment made:

Parcels post.

Express

When do you wish shipment made?

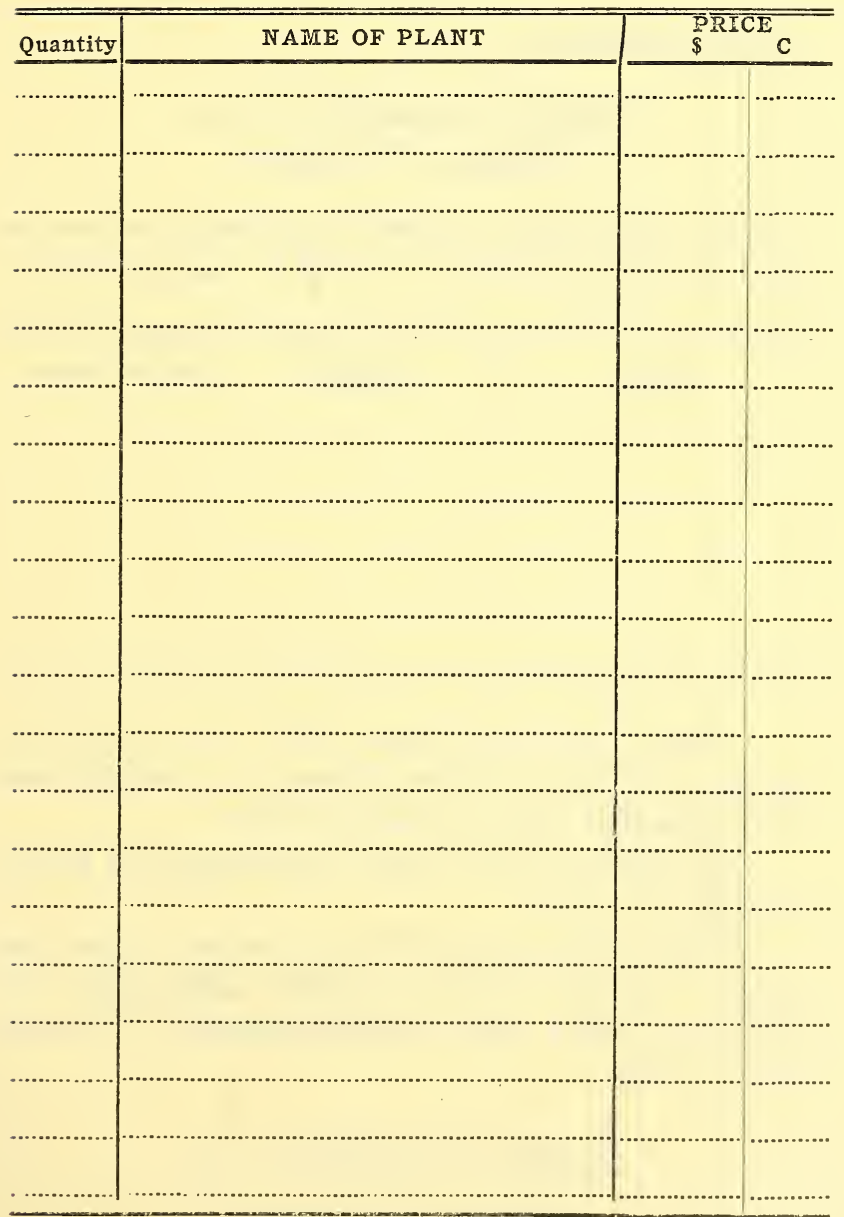




\section{PLEASE READ THIS WHEN YOU ORDER}

Please send remitiance with orde:. We do not solicit orders under $\$ 1.00$.

Packages will be sent with charges collect, either by express or parcels post, as you may specify.

This method is more satisfactory than attempting to quote postpaid prices, which, in many instances, must necessarily mean extremely small plants.

Six plants of a sort at the clozen rate; 50 of a sort at the hundred rate.

The greatest care is taken to supply stock true to name and effort is always made to satisfactorily adjust any error in this regard, but in accordance with the custom of the trade, no guarantee is given.

Make remittance to

EDDIE \& GAMWELL, Inc.

Bellingham, Washington

If you have friends interested in gardening and are inclined to send their addresses, we shall be most appreciative.

\begin{tabular}{|c|c|c|}
\hline Name & Address & City or Town \\
\hline & & \\
\hline & & \\
\hline & & \\
\hline & & \\
\hline
\end{tabular}

Then there is the "Lenten Rose"-do you know that one? It also is a Winter bloomer, but continues later in the Springtime past Lent, hence its name.

The flowers are pink, with white markings. A blooming plant for $\$ 1.50$.

Another dainty plant for your rockery is the blue Hepatica Triloba. One plant wouldn't make much of a showing, but half a dozen would do quite well. Price for the six, $\$ 1.25$.

EDDIE \& GAMWELL, Inc.

Bellingham, Washington 
Capitata-Neat, compact tufts, leaves whitish beneath. Heads of rich purple flowers on 8 to 12 -inch stems. May to July

Capitata Mooreana-A stronger-growing form of preceding. Larger tufts with larger flower heads on longer stems

Each

Cashmeriana-An improved P. Denticulata with deep violet flowers in dense, rounded heads on 12-inch stems. April to June

Chungensis-Beautiful pink flowers, often with orange-colored eye, in whorls on 18 to 24-inch stems. Large handsome foliage. Very rare

Cortusoides-A distinct Siberian species. Soft, wrinkled, heart-shaped leaves. Flowers of deep rose on 8 to 12 -inch stems. Will thrive in a light rich soil, in full sun

Denticulata-One of the first to bioom. Lovely large heads of lilac........

Farinosa, British "Birdseye Primrose."-Dainty rosy lilac flowers........

Florindae-Like a giant Sikkimensis; 3 to 4 feet mealy stems bearing umbels of drooping, brilliant sulphur-yellow blossoms with the scent of cowslips. June and July.

Frondosa-While this species is a native of the Balkans, it requires the same treatment as the Asiatic. Foliage mealy. Rosy flowers on 12 to 18 -inch stems during Spring and early Summer and again in the Fall. Very fine

Hellenae-One of the best of the dwarf growing species. Purple and canary

Japonica Splendens-Deep crimson flowers on 24 to 30 -inch stems. May and June and often again in th Fall

Juliae-Choice dwarf variety, with striking coloring of deep purple, yellow center. Found near waterfalls in the Caucasus.

Sikkimensis-Clusters of drooping, sweet-scented, pale-yellow blossoms; a lovely species from the Himalayas. Quite hardy. Likes moisture

PRIMULA Auricula (Alpine Primula)-Rosettes of thick, smooth leaves, sometimes farinose or mealy. Large flowers of various colors, all with a distinct eye, on 18 to 12-inch stems, from April to June. A cool, rich, fibrous loam with west or southwest exposure suits them.

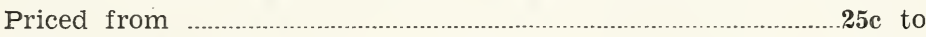

Aucaulis fl. pl.-Double lavender flowers on 3 to 6 -inch stems. While not rare, it is by no means common

PRIMULA Veris Hybrids-The old-fashioned Hardy Garden Primroses. Large flowers of many beautiful colors on 8 to 12-inch stems during early Spring. Can supply in mixture only..

Polyanthus "Glen Cove"-Large flowers of burnt orange on 10 to 12inch stems. A very choice variety

Polyanthus "Gold Star"--Large deep yellow flowers with a large orange-yellow star. Choice and rare.

Duplex (Hose-in-Hose)-Flowers with a double row of petals. Many rich colors

Queen of Heaven-Large blue flowers on 6 to 8 -inch stems. Very unusual and rare

PRUNELLA Incisa-Close tufts of dark green foliage, with spikes of violet-purple or pink flowers on 8 to 10 -inch stems, from June to August. Prefers partial shade 
PULMONARIA Angustifolia Azurea-Low-growing herbaceous plant with numerous deep blue flower-heads in early Spring. One of the first of the season, it is a most acceptable early harbinger.

PyReThrum Hybridum (Painted or Persian Daisy)-Invaluable for cut flowers during Summer and early Fall. Requires a deep, rich, moist loam in full sun, and resent being disturbed. Plants grown from seed from double-flowering varieties, of which a large percentage will come double, in white, crimson and shades of pink. Mixt. only

Tchihatchewi-A wonderful ground cover for dry exposures and rock work. Dense foliage of dark green, about 1 inch high, with Daisylike white flowers on 4 to 6-inch stems during Spring and Summer

RAMONDA (Sometimes called Ramondia)-Pyrenaica. A beautiful, dwarf, Alpine plant well adapted to the rock garden. Should be planted in small pockets in the rockery, in a slightly shaded, elevated position. Give deep, peaty soil. Foliage is dark green and crinkled, well grown specimens having 6 to 12 scapes of glorious lavender bloom

RANUNCULUS Gramineus-Neat dwarf species, with many bright yellow Buttercup-like flowers on 8 to 12 -inch stems, from April to June. Choice and rare

ROSEMARY-An excellent plant for dry places in the rockery. Spikes leafy grey and green aromatic foliage, with small clusters of lilac flowers. Should be pruned back each year; 12 to 18 inches....35c to

SAGINA Subulata-An excellent ground cover for semi-shaded places. Evergreen, densely tufted, cushion-like plant from the Island of Corsica. During early summer the tiny white flowers on slender stems create a white, cloud-like effect over the sheets of mossy green. Good clumps

SALVIA-Shrubby, sage-like plants.

Greggii-Native of Texas and Mexico; makes a shapely, bushy plant, about 2 feet high, with masses of rich and luminous brilliant carmine flowers from August to October. Needs protection during extreme cold

Virgata Nemorosa-One of the most attractive plants in cultivation. Neat bushes of Sage-like foliage, smothered with attractive spikes of brilliant purple flowers from June to August. Very effective in the border

SANGUINARIA Canadensis (Bloodroot)-An Eastern native. Pure white flowers with golden-yellow stamens. Flowers are an inch across and on 6-inch stems during May and June. Handsome glaucous foliage.

SAPONARIA Ocymoides-An excellent plant for dry banks or poor soils. During June and July brilliant masses of bright rose-pink flowers on trailing stems hang down over the rocks. Striking color mass...

SAXIFRAGA-This is perhaps the largest race of Alpines and is indispensable in the rock garden. As might be expected in so extensive a family, there is much variation as to foliage, flowers and habits of growth. We divide them into several sections. 
ENCRUSTED VARIETIES-Form rosettes of narrow, leathery leaves, which are, in most cases, heavily encrusted with lime deposits, giving the plants a braided, silvery appearance. They are of the greatest ornament to the rock garden, even when not in flower. Most all bloom in May and June, and will thrive in a light, well-drained, stony or gritty soil. They show to best advantage in raised rocky positions, or wedged in between several rocks. The majority enjoy full sun.

Aizoon-A treasure for the Alpine garden, forming rosettes of silvery beaded leaves and bearing plumes of creamy white blossoms, 6 to 8 inches high, in early summer

Aizoon Rosea-Similar to above, but with deep rose flowers..

Aizoon Balcana-Incurved rosettes and densely purple or crimsonspeckled flowers. Formerly listed as A. Rosea

Aizoon Baldensis-A minute little form, rivaling the neat cushions of some of the choicest Kabschia forms. Scarcely 2 inches high when in flower. White

Aizoon Flavescens-Clear, lemon-yellow flowers. 8 inches

Aizoon Lagaveana-Worth growing for its neat, compact rosettes alone. Ruddy stems, 6 inches high, with 4 to 6 thick and wax-like creamy-white flowers on each stem

Aizoon Pectinata-Flattened rosettes, rather heavily silver braided. White, with red dots

Andrewsii-Long, narrow foliage, sharp-toothed. White flowers, thickly dotted with red. The true plant seems to be rare, being a garden hybrid between S. Geum and S. Aizoon Guthriana. We guarantee these to be true

Cartilaginea-Distinct and rare. The rather rigid leaves are sharply pointed and resemble small Agaves. Graceful 8 to 10-inch flower spikes with white or soft pink flowers.

Cochlearis-Choice little domes of silvered rosettes. Graceful redstemmed sprays of large, snow-white flowers; 4 inches.

Cotyledon Caterhamenss-Hybrid of outstanding merit. Stems of two feet or more with branching sprays of white dotted with red, giving a deep pink effect

Cotyledon Pyramidalis-Broad-leaved rosettes, which turn a reddish color in Winter. Large panicles of white flowers, speckled with

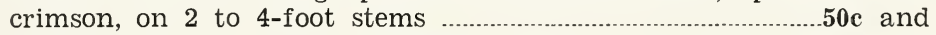

Gaudini-Hybrid between Cotyledon and Aizoon. Pink-spotted white

Hostii-Rare species. A strong grower with rosettes of narrow grey leaves. White flowers, sometimes dotted purple near the center of flower, on 8 to 12 -inch stems

LaGaveana-Small edition of the Aizoon bearing creamy white flowers

Lingulata-Loose spidery rosettes of long narrow leaves, encrusted with lime, from which rise lovely plumes of white.

Lingulata Lantoscana Bellardii-This is a distinct variety requiring a little shade. Long, narrow leaves with erect panicles of white flowers

Longifolia, The "Queen of Saxifrages"-Native of the Spanish Pyranees. Rosettes beautifully encrusted, lovely enough in themselves, but the crowning glory is the immense panicle of white bloom, 1 to 2 feet long. Very showy 
Macnabiana-Medium sized rosettes which assume rich Autumn tints in the Fall; 12-inch spikes of white flowers speckled with crimson

Pectinata-Hybrid between Aizoon and Incrustata. Flattened rosettes, heavily silvered. White bloom

Each

KABSCHIA SECTION-These high Alpine plants are of dwarf tufted habit, and many of them have their foliage more or less encrusted with silvery lime deposits. All early Spring flowering, from March to May. They all answer to moraine treatment, but may also be grown on ledges or in crevices filled with very gritty soil. Best protected from the direct rays of the midsummer afternoon sun, by placing on north or east side of rock. Well worth the little extra work.

Apiculata-Spiny green rosettes, primrose-yellow flowers on 2 to 3inch stems

Apiculata Alba-Pure white flowering form of preceding …_.......... $\quad .50$

Boryii-Compact grey-green cushions with large white flowers in early Spring. A little gem

Burseriana Magna-Tiny hedgehog-like plant. Pure white, red-

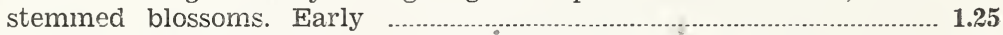

Burseriana Sulphurea-Glorious with little yellow flowers .................. 1.00

Elizabethae-Small cushions of grey foliage. Ample blossoms of pale

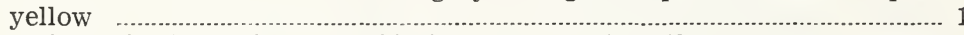

Ferdinandi Coburgi-New. Similar but better than above, deeper

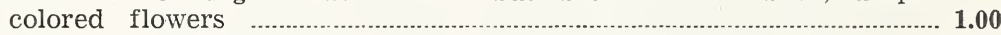

Godseffiana-Spreading mat of bluish grey. Yellow flowers ................ .75

Irvingii-The lovely colored hybrid from Burseriana. From a dense little cushion of grey-green there are thrown up on 2-inch stems masses of pink blossoms

Lutea-Viridis-Charming species. Pendant yellow flowers on green mats. Very small and late

Petraschi-Choice little silvery cushions with large white blossoms in very early spring.

Rochelliana-Compact silvery rosettes with neat little blossoms of creamy white

MOSSY SECTION-Have been cross-bred and hybridized to such an extent that it is impossibie to assign many of the distinctive color forms to botanical species. They all form cushions or mossy carpets of emerald green, and all appreciate partially shaded and moist but not stagnant positions with the addition of some leafmold and grit to a loamy soil. Vary in height from 2 or 3 inches to. 6 inches or more. April and May see most of them in their glory.

Caespitosa-A native species. Creamy-white flowers. Superior to many of the highly prized European species; 4 to 6 inches..........................

Cotswold Cream-Rich cream, dark green foliage.....................................

Decipiens Alba-Covered with early white flowers

Decipiens Rosea-Similar with bright pink flowers ............................. .35

Decipiens Grandiflora Bathoniensis-Blooms of large size borne in generous sprays of brilliant blood crimson, changing to rose pink. One of the best of the colored ones......

Guilford Seedling-New hybrid with deep crimson flowers. A good one $\mathbf{5 0}$

H. D. Stokes-Bright carmine. Likes bright sun ........................ $\quad \mathbf{5 0}$

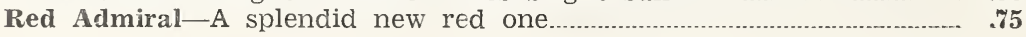


Each

Sir Douglas Haig-Deep crimson

Wallacei-A fine trailer with dazzling white flowers................................. .

PORPHYRION SECTION

For moist edges of rock work or border, blooming very early.

Oppositifolia Splendens-Intensely brliliant masses of purple crimson, blooming in March

\section{LONDON PRIDE SECTION:}

Cuniefolia-A tiny "London Pride," with dainty pink flowers very early

Primuloides-Elliott's Variety. Compact, little happy looking Alpine, bearing delicate showers of carmine-rose blossoms. Choice...

Umbrosa (London Pride)-Nothing prettier for a cool, shady spot, associated with Myosotis Palustris. Dark green foliage, and 10 to 15-inch spikes of white flowers, speckled pink

MEGASEA-Large-Leaved Section.

Splendid for borders, rough rockery banks, etc. Handsome plants. Cordifolia (Megasea)-Large, glossy and leathery leaves, richly colored in Autumn and Winter. Heads of soft rose flowers partly hidden in the foliage. Best in partial shade. Protect from the burning east winds

SCABIOSA (Pincushion Flower) - These handsome border plants succeed in any ordinary soil if well drained and in a sunny location. Most varieties are too tall for the rockery.

Caucasica-An excellent cut flower, and one of the most persistent bloomers in the perennial border. Soft shade of lavender flowers on 12 to 18 -inch stems, from June to September.

Graminifolia-Leaves somewhat silvery. Flowers of pale blue or soft rose. Very drought resistant, flowering from June to October; 8 -inch. This is a rock garden type. The others are better suited to the border

Japonica-Lavender-blue flowers in rounded heads, on 2-foot stems, from September to November

SCUTELLARIA Alpina-A spreading plant 8 to 12 inches high, with large purple and white flowers during July and August. A light soil in full sun

Orientalis-Semi-prostrate, grey green foliage and yellow flowers........

\section{SEDUM-The Stonecrops.}

An interesting race of plants, almost all of which rejoice in the poorest of soil (sandy preferred) and dry and arid positions. Many of them are well worth a place for the low carpets of richly colored fleshy leaves alone.

Acre (Wallpepper)-An evergreen creeper and mats of purest gold during June and July

Album-Light green, sausage-shaped foliage, white flowers

Anglicum-Neat plant. Grey-green foliage, white flowers, sometimes pinkish 
Brevifolium-Like tiny silver and pink pebbles, foliage covered with mealy pubescence. Flowers white with pink anthers. Good for dry ledge

Dasyphyllum-One of the smallest of the Sedums. Bluish-Grey beads set tightly on frail stems, covered in Summer with small blushing stars. Walls and sunny crevices; 2 inches

Ewersii-A deciduous species. Blue-grey leaves and large heads of rosypurple flowers on 8 to 10 -inch stems

Glaucum-Creeping mats of blue-green foliage, with small white flowers touched with pink, during midsummer; 2 inches

Hispanicum-Leaves become reddish studded with tiny hyaline tips giving the plant a misty appearance. Very attractive.

Kamtschaticum-A trailing species, with large orange-yellow flowers from June to September on 4 to 6 -inch stems. The seed heads turn to bright crimson. Very effective

Lydium-Dwarf carpets of brightest green, which in dry and fully exposed positions and the poor soil it prefers, turn to a lovely rich deep red. Small heads of white flowers on 2-inch stems during Summer

Middendorffianum-A choice type from Amurland. Deep green tufted foliage which becomes red in winter. Yellow flowers in a flattened cyme

Murale (Pink Sea Foam)-Reddish-purple evergreen foilage, white flowers which have a distinct pink center, on 4 to 8 -inch stems. New and interesting

Nevii-Foliage in attractive terminal rosettes. White flowers in forked cymes. Very distinct variety

Oreganum-A pretty native. Short upstanding stems, with fat little paddle-shaped leaves which turn rich bronzy-red. Large flat heads of bright golden flowers

Pilosum-Foliage in rosettes. Pretty little pink flowers

Pruinatum Fosterianum-Spiny foliage turning bronze in Fall. Yellow flowers

Pulchellum-Fluffy pink clawlike heads in Autumn. Enjoys some shade

Reflexum Cristatum-Has fasciated stems forming a crest like a cockscomb. Very curious

Sexangulare--Quite prostrate. Good for a carpet bed............................. Sieboldii-A Japanese species. Red-edged glaucous foliage. Large heads of pink flowers from September to November. Unexcelled for rock walls, hanging baskets, etc. As valuable for its foliage as for its flowers, which come at a time when the rockery needs color.

Spathulifolium-From the Sucia Islands in the Gulf of Georgia. Grows on rocks requiring little moisture. Creeping barren stems with terminal rosettes of spathulate leaves. Terminal cymes of yellow flowers

Spectabilis-Erect-growing, deciduous species from Japan. Large, fleshy, glaucous leaves and flat heads of rose-pink flowers on 10 to 15 -inch stems. August and September.

Spectabilis Brilliant-Purplish-red flowering form of preceding.

Spurium-A very desirable Sedum for ground cover. Dense foliage, a little over an inch in height, often taking on a bronze coloring. White flowers

Spurium Coccineum-Same as the preceding with showy red or carmine flowers 
SEMPERVIVUM (Living Forever), Houseleeks or Hen-and-Chickens-All true mountaineers, and generally found on sun-baked rocks, in the merest deposits of soil. Their only requirements are perfect drainage and full sun. They form rosettes of succulent leaves of varying colors. Flower stems from 6 to 10 inches high, blooming from July to September. Large trusses of bloom.

Arachnoideum-Tips of foliage connected with long, soft white hairs. One of the neatest. Salmon pink

Browni--Very distinct, with dark green foliage, tipped reddish-brown. Flowers red

Glaucum-Medium rosettes of pale glaucous green leaves …................... .25

Laggeri-A large rosette form of Arachnoideum. Lovely grey-green foliage. Flowers rose

Montanum-Rather small rosettes of dull green, tipped red................... .25

Pallidium-Rosettes of light green foliage, tipped red

Pyrenaicum-Handsomely formed dark red rosettes.................................

Tectorum-Pale green with a distinct red-brown tip. Red ….............. .25

Triste-Lower part of leaves dull drab-green, the whole upper part bright red-brown. Large bright red flowers

We also have: Accuminatum, Blandum, Rubicundum, Comolii, Doleanum, Fimbriatum, Funckii, Glebiferum, Laggeri and others, which we shall be glad to list on request.

SENECIO Tyrolensis-Very dwarf and compact, with finely cut foliage and heads of brilliant orange Daisy-like flowers. Prefer low; moist places, but will do well in full sun if given a little water; 6 to 8 inches, June and July

SHORTIA Galacifolia-A lovely white-flowered evergreen. Requires peat soil and enjoys shade

SILENE Acaulis (Moss or Cushion Pink) - A typical high Alpine. Solid mats of bright green Moss-like foliage, studded with small, almost stemless pink flowers in June and July. Requires a little shade durthe hottest part of our Summers

Hookeri-One of the most striking natives of prostrate habit. Soft grey foliage and large deeply fringed blossoms of a soft pink. Light sandy soil or moraine and sunny positions

Maritima-Compact masses of glaucous blue foliage, covered with pinkish-white flowers from June to August. Very desirable for hot, dry spots in the rockery, or for rock walls; 2 to 3 inches.

Saxifraga-Somewhat shrubby, with bright green foliage, above which appear dainty white flowers all Summer; 6 inches

Schafta-A trailing variety, with masses of rosy-purple flowers from August to October, giving color when needed

SISYRINCHIUM Grandiflorum (Grass Widow)-Large, bright purple nodding bells on 8 to 12 -inch stems in early Spring. Native

SOLDANEL A Alpina-A high Alpine plant, requiring cool expcsures and and gritty, peaty soil with moisture in Summer and protection from overhead wet from November until March. This generally induces them to flower quite happily. Belong to the Primula family and form low-growing mats of round leathery leaves and fringed funnelshaped nodding bells of violet on graceful stems. Very choice and rare 
STACHYS Lanata (Woolly Woundwort)-Silver-grey foliage.

STATICE Globularifolia-A very dwarf and compact tuft. Flower stem

3 to 4 inches long, with pinkish flowers. Rare

Incana Nana-Dwarf and prostrate. Greyish-white flowers on 6 to 8inch stems, fowers lasting for several months while on plant

STOKESIA Lilacina (Stokes' Aster)-Large, Aster-like flowers on 10 to 15-inch stems during August and September. Lavender.

SYNTHYRIS Rotundifolia-A Washington native shade plant. Big, round leaves and spikes of lavender or blue flowers, 6 to 8 inches high. One of the very first plants to bloom in the Spring.

Reniformis-Also a native of Washington, rather better than rotundifolia. Kidney-shaped leathery leaves and fluffy spikes of clear lavender-blue in early Spring

TEUCRIUM Chamaedrys-A picturesque sub-shrub. Glossy green evergreen foliage and spikes of bright rose flowers from July to September; 12 inches

THLASPI Bulbosum-Basal leaves in rosettes, a very neat and compact tuft. Violet flowers in small heads on 3 to 6 -inch stems, during March and April. For a cool, moist spot.

THYMUS (Thyme)-The creeping varieties are indispensable for carpeting hot, dry spots in the rockery, and both creeping and sub-shrubby varieties are invaluable for dry rock walls.

Azoricus-Makes neat domes of evergreen foliage, with lilac colored flowers. Not as rampant as the Serpyllus types

Golden Variegated-Dwarf sub-shrubby type, fragrant, variegated foliage; 8 to 12 inches

Silver Variegated-Form of preceding..

Serpylium Album-The white flowering, creeping Thyme. The Serpyllus type makes excellent ground cover for hot, dry spots............

Serpyllum Carneus-Pink flowering form of preceding..........................

Serpylium Coccineum-Crimson flowering form of preceding................

Serpyllum Lanuginosa (Woolly Thyme)-Fragrant grey woolly foliage and lavender-pink flowers. Very popular.

Nitidus-A very choice sub-shrub. Like a miniature silvery Irish Yew, covering itself with rosy-lilac flowers in June; 8 to 12 inches. Small plants, 35c; large plants.

Fragmentaire-Very fragrant little Thyme for stepping stones.

TUNICA Saxifraga-A pretty tufted plant with fine foliage and masses of light pink flowers all Summer. Excellent for rock walls.

VALERIANA Coccineum-A good plant for dry rock walls. Showy heads of old rose or pink flowers on 18 to 24 -inch stems. Also good cut flowers. May to August

Alba-White flowering form of preceding

VERBENA Aubletia or Canadensis-While a native of this country, it is practically unknown in our rockeries and gardens, yet in England it is planted extensively. Masses of pink or rosy-pink flowers on 12 to 18-inch stems, from July to October 
Venesa-Tuberous rooted, spreading by root growth. Heads of violet flowers, often veined, on 12 to 18 -inch stems. Summer.

VERONICA-Contains some of the most beautiful of our blue-flowering plants for the border and rockery.

Amethystina-Blue flowers on slender 12 to 18-inch stems during May and June. Of compact habit.

Incana-A very beautiful, compact, low-growing plant. The 8 to 12-in. spikes of deep violet flowers make a pretty contrast against the silver-grey foliage. July ano August

Longifolia Subsessilis-The true plant. Pretty foliage and 12 to 24-in. spikes of beautiful blue flowers from July to September. One of the finest blue flowers in the garden.

Prostrata (Rupestris)-Carpets of olive-green foliage, smothered with dainty spikes of rich blue flowers, May and June .......................

Repens-Bright green mats, studded with whitish lavender flowers, June and July. Prefers shady, most positions

Saxatilis-Neat evergreen creeper, with dark shiny foliage. Bright blue flowers on 4 to 6 -inch stems. Summer

Spicata-Dark green foliage with 12-inch spikes of blue flowers.

Spicata Alba-White flowering form of preceding, somewhat more dwarf and compact

Spicata Rosea-Spikes of soft pink flowers.

VIOLA-The Viola is not as well known in America as it should be. Very few other plants have as long a flowering period. They succeed best in a deep, well-enriched soil, well drained, but with plenty of water during the hot Summer. They seem to prefer a light shade during the hottest part of the midsummer days, but will thrive in full sun. Do not allow to go to seed, and in Midsummer cut back all straggling growth, to allow plants to make new tufts.

Alpina-Rather long, narrow flowers of a deep purple, on 3 to 6-inch stems. A good Alpine for a sunny spot. June to October.

Apricot-Large blossoms of various shades of apricot yellow from May to September; 6 to 8 inches

Bosniaca-Large mats covered with reddish-violet or amethyst colored flowers from May to September. A distinct Alpine species.

Florariensis-The nearest to a Winter-blooming Viola that can be found. Medium sized flowers of a pleasing shade of blue. Practically all year; 6 to 8 inches

G. Wermig-A tufted variety, forming clumps of pretty foliage, covered with rather small, long-faced flowers of blue, throughout the Summer; 6 to 8 inches

Gracilis "Lord Nelson"-Large flowers of a glowing purple, on long stems. One of the very best of the Gracilis type

Haslemere-A hybrid with large flowers of lilac-pink, with some variations. A continuous bloomer

Jersey Gem-The best all-around Viola yet introduced. Large flowers of a pure violet, slightly perfumed, on 6 to 10 -inch stems, from early Spring to late Fall

Jersey Jewel-Flowers somewhat larger than Jersey Gem, of a rich purple. A new and very rare variety, excellent for shady places........

Lutea Splendens-A fine yellow flowering variety. All Summer.. 
Pedata (Bird's Foot) -Native of the Eastern States. Cut-leaf foliage and large pale violet flowers on short stems. Requires an acid soil....

Pedata Bicolor-Upper petals violet and lower ones light-blue, making

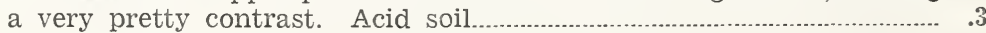

Portland Gem-A new introduction. As persistent in blooming as Viola Jersey Gem, but of a lovely shade of lavender-blue with a very small yellow eye. Somewhat larger than Jersey Gem. Plants commencing to bloom in November will bloom incessantly throughout the Winter

Riviniana-A true Alpine Viola. Small light blue flowers on 2 to 3inch stems during June and July, and again during September and October if plants are sheared back during August...

Sylvestris Rosea-A distinct dwarf, close-growing little species, with fine, rosy-pink flowers. Excellent for rockery, border or naturalizing

White Wermig-A white-flowering form of this popular Viola.

White Jersey Gem-A white-flowering form of Jersey Gem. The best of the white Violas

One each of Twelve Varieties of Viola, Our Selection, Postpaid, \$2.50.

VIOLA ODORATA (Violet)-

Gov. Herrick-Large shining leaves and flowers of rich, deep purple....

Baroness Rothschild-Rich purple; very free-flowering...

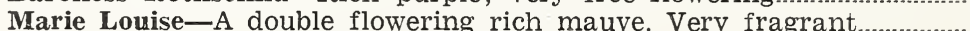

Swanley White-A double flowering white.

\section{WAHLENBERGIA-Tufted Harebell-Edraianthus.}

Beautiful free-flowering plants, especially suited to the rock garden. They are closely related to the Campanulas and require about the same treatment.

Dalmatica-A choice Alpine for fissures in rockery. Blue Harebell flowers in clusters

Dinarica-French-grey foliage, clusters of blue bells

Graminifolia-Grass-like foliage and skyblue flowers. Very fine............

Kitaibeli-Similar, but hairy shorter leaves. Bright blue flowers........

Pumila-Greyish foliage and tiny blue bells..

Serpyllifolia-Lovely plant from Dalmatia. Large, beautiful, purple bells in July. Good wall plant

WULFENIA Carinthiaca-Close tuffets of thick leathery leaves, from which spring thick, stocky stems, densely set with bright blue flowers during June and July; 8 to 12 inches

ZAUSCHNERIA Californica-An excellent plant for rock walls, where it receives full sun and the foliage may hang over a rock or ledge. Large tubular flowers of a brilliant scarlet. Remarkably drought resistant 


\section{LIST OF SCREE OR MORAINE PLANTS}

Androsace Brigantiaca

Androsace Laggeri

Androsace Lactea

Androsace Villosa

Androsace Vitaliana

Armeria Caespitosa

Campanula Excisa

Campanula Waldestiana

Campanula Rainerii

Campanula Zoysii

Dianthus Alpinus

Dianthus Callizonas

Dianthus Freynei

Dianthus Microlepsis

Douglasia Vitaliana

Douglasia Laevigata

Draba in variety

Gentiana Verna
Leontopodium
Papava Alpinum
Penstemon Davidsoni
Penstemon Rupicola
Potentilla Nitida
Potentilla Villosa
Potentilla Tonguei
Potentilla Nevadensis
Lupinus Lyalli
Linaria Alpina
Saxifraga-Any of the Kabschia sec- tion, also the smaller encrusted varis eties and oppositifolia varieties.
Scutellaria Alpina
Silene Acaulis Pumilio, Elizabethae
Wahlenbergia Pumilio, and small vari- eties

\section{SUITABLE FLOWERS FOR SHADY PLACES}

Almost all rock plants do well in sunny places, or at least partial shade, but we list a few plants that are especially adaptable to shady locations.

Acaena

Astilbe Simplicifolia

Ajuga

Epimedium

Hutchinsia

Androsace Lanuginosa (partial)

Androsace Vitaliana (partial)

Iberis

Omphalodes

Oxalis

Anemone Blanda

Anemone Hepatica Triloba

Aquilegia (partial)

Arenarias

Calceolaria

Cypripedium

Erica Carnea and other Heathers

Campanula Steveni, Standsfieldi,

Riverslea, Mirandi (partial)

Corydalis, in variety

Cotula Squalida

Primulas, in variety

Ramonda

Hypericum (partial)

Saxifraga, Mossy varieties,

Cuniefolia, Tenella, Primuloides, Oppositifolia, Andrewsii, etc.

Soldanella

Polygonum Vaccinifolium

Shortia

Violas, in variety

\section{PLANTS FOR PAVING STONES}

Acaena (all)

Mazus Rugosa

Achillea Argentea

Antennaria Rosea Nana

Arenaria Balerica

Arenaria Purpurescens

Bellum Mìnutum

Campanula Pusilla, and varieties.

Cortula Squalida

Dianthus Alpinus and Albus

Douglasia Vitaliana

Douglasia Laegivata

Draba (all)

Erinus, both

Geranium Pylzowianum

Gypsophila Cerastoides

Gypsophila Repens

Linaria Alpina

Mazus Pumilio
Potentilla Cinerea

Saxifrages-Some of the Kabschia section make excellent subjects

Sedums-Many of the Sedums are very suitable, especially the Lydiums.

Sedum Dasyphyllum

Sedum Sexangulare

Silene Acaulis, and varieties

Thymus Serpyllum

Tunica Saxifraga

Veronica Repens

Veronica Teucrium Dubia

Veronica Teucrium Dubia Rosea

Viola Calcarata

Viola Glacialis 


\section{LIST OF PLANTS FOR WALL GARDENS}

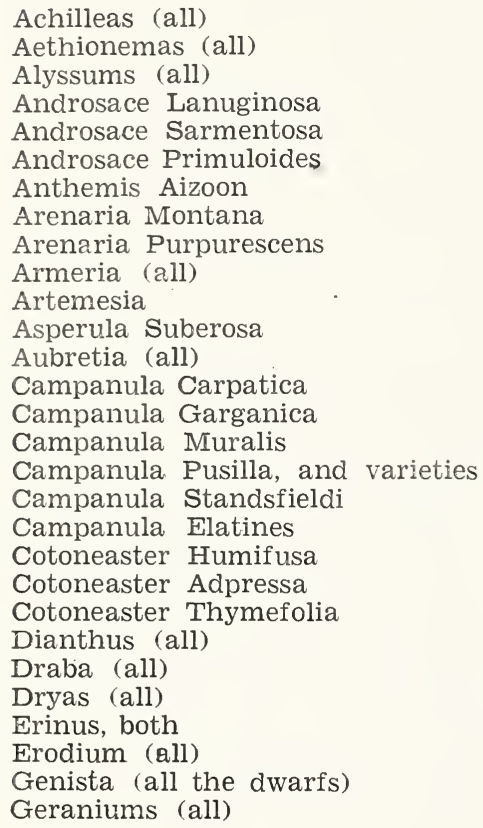

\author{
Gypsophila Cerastoides \\ Gypsophila Repens \\ Helianthemum (all) \\ Hypericum (all) \\ Iberis (all) \\ Linum (all) \\ Lithospermum (all) \\ Omphalodes Cornifolia (shady part) \\ Onosma \\ Penstemons (all) \\ Phlox, Subulata varieties \\ Amoena \\ Adsurgens \\ Divaricata \\ Pilosa \\ Polygonum Vaccinifolium \\ Potentilla Tonguei \\ Primula Auricula varieties \\ Ramondia, shady north side \\ Saponaria Ocymoides \\ Sedums, many varieties, especially \\ Spathulifolium and Spurium \\ Silene Acaulis, and varieties \\ Thymus (all) \\ Tunica Saxifraga \\ Veronica Teucrium Dubia \\ Veronica Rupestris \\ Veronica Guthrieana
}




\section{Japanese Irises}

This lovely flower originated in the Amur District of Manchuria. Lovely as it is in its wild form the Japanese gardeners, by some process quite unknown to plantsmen of the rest of the world, have evolved an even more lovely type for the cultivated garden.

In many of these evolved types the styles have been more or less converted into petals resulting in what seems to be double flowers. In many cases the standards have ceased to be erect and have become almost as wide as the falls, thus giving the flower a flattened appearance that is unique among irises and make the Japanese iris one of the most striking plants of the garden.

The magnificence of these exotics from the Orient is such that written descriptions do them scant justice. Many of the flowers, particularly the 3petal type, measure eight or nine inches across. The flowers are almost flat and are borne on strong, upright stems with foliage of narrow, rapier-like character making an ornamental addition to the hardy border even when not in flower. Japanese irises are of easy culture and are hardy everywhere.

From a private estate we have just secured a fine collection in choice, named varieties. They have been grown with the painstaking care of an experienced enthusiast and are especially fine plants of the large-flowering type.

Japanese irises form a striking feature, either in single beds or grouped in the perennial border. They like rich soil, without lime and for about thirty days before they bloom, do best with a liberal amount of water. beauty.

These selected varieties of this lovely flower are marvelous in size and

I-chi-ban -Six petals, outer ones round, mauve white with lighter (1) mauve reticulation, center lines lavender. Canary spot at base of petal. Inner petals two inches long, pinkish lavender. Standard same. A beautiful flower. Diameter 8 in....

Ni-ban-kul-san-Three petals, bluish white, heavily reticulated with bluish

(2) lavender. Styles reddish purple. Yellow blotch on base of petal

Ni-ju-go-ban -Six petals, round light mauve, deep lavender reticulations. Yellow at base. Styles solid, deep lavender surrounded by small, undeveloped petals of light mauve, reticulated with reddish purple. The general effect of the bloom is bluepurple

Ha-chi-ju-san-Smalland good, having three mauve petals heavily reticu(83) lated with deep pinkish lavender with yellow blotch at base of petals

Ni-ju-ro-ko - Six round petals, light mauve, with blue reticulations. A (26) fine large flower. Standards same color as reticulations....

Ha-chi-ban-Three petals, dark reddish purple, solid color. Small touch of

(8) color at base of petals. Standards same color. Diameter seven and one-half inches

Ju-ichi -Three large petals, white, light mauve reticulations. Can-

(11)

Ju-ni-ban

(12)

Ju-go-ban

(15)

Ju-ro-ku

(16) ary center. Standards reddish purple. A good one.............

-Three large, reddish lavender petals and styles with canary at base of petals. Diameter of flowers 8 to 9 inches............. -One of the earliest to open. Three petals, deep purple, slightly flecked with white.

-Three petals, nearly white, flushed with lavender with deeper lavender reticulations. Base of petals white with yellow center. Standards, rich purple. 
Ju-shi-chi - Three petals, reddish purple, white reticulations. Small (17) canary spot at base of petals. Standard same color. A large, attractive flower

Ju-ku-ban-san-A beautiful, double flower. Six petals nearly white with (19) mauve reticulation and canary of base. Styles white with mauve tips and edges

Ni-ju-kul-ban-A lovely single, five inches in diameter. Light mauve with (22) bluish reticulations and yellow blotch at base of petals....

Ni-ju-ni -A good single, bluish white petals, heavily reticulated with reddish purple. Yellow blotch at base of petals.

Nu-ju-ro-ko-ban-Startlingly beautiful. Resembles Ni-ju-go-ban above, (26) except reticulations are blue instead of lavender. Diameter of flower 7 to 8 inches.

Ni-ju-ha-chi -A double flower. Large petals, mauve-white with reddish

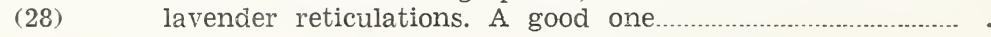

San-ju-sen -A lovely, large double blossom. Prevailing color is pink, (33) shading to white at center of petal, with canary center stripe. Styles are white with pink tips.

San-ju-ni -An attractive, semi-double blossom. Prevailing color, (32) mauve with deeper mauve reticulations. Styles, a clear, purplish blue

San-ju-shi - Three large standards of light mauve, flecked with deep (34) lavender. Styles same color, with white edges.....................

San-jı-go —Standards, reddish purple. Falls larger than standards (35) with purplish shading over white, reticulated with a

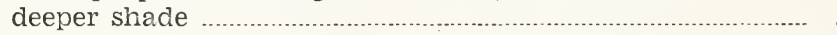

San-ju-ro-ku —Standards, clear purplish-blue. Falls, mauve to purple (36) with purple stripe and yellow base $\quad$.........................................

Shi-ju-ban -Both falls and standards good royal purple color, with (40) slight canary shading at base. Eight inches in diameter...

Go-ju-go - A single, white flower with canary center and some mauve (55) shading on edge of petal. A very dainty blossom..............

Go-ju-ku-yed-Three large falls of mauve, with heavy reticulations of (59) bluish purple. Standards smaller, of purplish red. Very rich effect. Eight to nine inches, diameter. purple reticulations and standards of deep bluish-purple 
Ro-ku-ju-hachi-A semi-double blossom. Prevailing effect, rich dark pur(68) ple. A showy blossom .50

Ro-ku-ju-ku -A single flower, mauve with reddish purple reticulations .50 (69)

Shi-chi-ju - Practically a pure white blossom, having oniy a canary (70) tint at base of its three large falls. Standards, pure white

Shi-chi-ju-san-A double blossom. Petals large, round, of dark purplish (73 red. Diameter, 8 to 10 inches......

Shi-chi-ju-chi-The large falls are light blue with yellow at base. Stand(74) ards are white, tipped with a light shade of lilac blue.

Shi-chi-ju-ro-ku-A single flower whose roundish falls are white with (76) faint lavender reticulations, having a suggestion of canary at base. The small standards are of a delicate reddish purple. Very dainty appearance.

Shi-chi-ju-ku-Blossoms nearly single, of true Elks' purple color. Stand(79) ards are small and falls, large round petals. A fine flower

Ha-chi-ju-hachi-A semi-double blossom. Three large falls, white with (88) slight canary centers. Standards, white with pink edge. A beautiful blossom

Ku-ju-i-chi -A single, medium size flower with three white petals of (90) dainty appearance

Ku-ju-shi -A nearly solid color, double blossom of deep reddish pur(94) ple, with yellow shading at base of each petal. Diameter, eight inches.

Ku-ju-go - Three large falls of white with bluish reticulations and (95) canary spot at base. Standards are small, of mottled white and light purple. A fine flower

Ku-ju-ha-chi-A good solid white blossom with light canary tint at base of standards and falls. A medium size flower.

We will send a good selection of our choice for $\$ 2.00$ for five blooming size clumps of these rare Japanese irises. 


\section{QUALITY ROSES}

Roses, like most humans, respond generously to the care, attention and affection bestowed upon them during their formative period. Hence, in building a rose garden one should endeavor to provide the soil, food and moisture conditions that suit the plants as nearly as possible and thus induce strong growth and abundant bloom.

There are many good books available in all public libraries that tell how to do this, and if you are a member of the American Rose Society, there are experienced enthusiasts in your own vicinity who will interest themselves in your problems and cheerfully answer your questions.

In choosing your plants, well grown stock of tested varieties should be selected and arranged in colors to harmonize effectively. Quality of material is very essential and it is almost imperative to secure plants with strong root systems. The best are those grown two years at least in the open field, under climatic conditions that will insure hardiness and give them the strength and stamina necessary to produce the perfect flower and glorious bloom so ardently desired by all rose lovers.

Our rose bushes are of that sort. They are nurtured in the cool, moist climate of the North Pacific coast and will grow and bloom anywhere, under good garden conditions.

Our Bellingham plantation is as far north as Quebec and our British Columbia fields even farther than that. Our plants are grown in virgin soil, under clean conditions within two hours drive of the perpetual snows. We pride ourselves on shipping only good strong stock, so packed as to safely reach any part of the country.

\section{EDDIE \& GAMWELL, Inc.}




\section{Roses of Recent Introduction and Novelties}

Here are some of the newer Roses that have been tried and found satisfactory in color, form and hardiness. Most of them have been subjected to rigorous conditions at our British Columbian plantation, where for twenty years roses have been grown for the cold, Canadian countries, in addition to having been tested in the basin of Puget Sound.

LADY ROUNDWAY -A pernetiana produced by B. R. Cant \& Sons, Ltd., Color is deep coppery chrome of same shade throughout; medium sized blooms, strong, bushy habit; free flowering and sweetly scented $\mathbf{1 . 5 0}$

ELVIRA ARAMAYO-A pernetiana from Looymans \& Sons. Indian red in color, a new and beautiful shade. Very free flowering. Flowers resemble huge carnations. A distinct novelty.

MRS. TALBOT O'FARRELL-A hybrid tea. The outside of the petals is lemon yellow, flushed and splashed deep cerise to crimson. Inside of petals is deep cerise, heavily flushed and veined orange-yellow and bronze. Foliage dark green. Likely to become a favorite.

PRESIDENT WILSON-One of Easleas good hybrid teas. Immense bright pink blooms of exceedingly handsome quality, with a luminous glow overspreading its petals. Liberal bloomer..

SALMON SPRAY-An interesting polyantha from Austria with rich, salmon-pink flowers produced continuously in great heads of bloom. Makes a stocky plant three feet high, hence is better as a specimen plant on the lawn or in the border.

SCARLET GLORY-A very floriferous garden and bedding rose of great merit. Well formed blooms of bright vermillion_scarlet producing brilliant effect in masses.

SIMONE DAMAURY-A sweetly scented hybrid tea of bright velvety crimson. A vigorous and effective bedding plant.

WHITE ENSIGN-A hybrid tea well described by its name. Pure white flowers of perfect shape produced in great abundance. Plant stocky with dark green foliage.

DAME EDITH HELEN ( $\mathrm{H}$. T.) - Pure glowing pink, not too deep. A noble flower, large and fragrant, full, of perfect form and opening well in all weathers. Delightfully fragrant. Gold Medal N. R. S..

DORIS DICKSON (H. T.)-Medium sized buds and extremely fragrant double flowers of orange-cream, heavily veined with bright cherry red. Good stem. Vigorous and prolific plant...

FRANK READER (H. T.) - Long buds and beautifully pointed blooms of pale yellow, showing a center of rich apricot, when fully open. Sweetly scented. Vigorous

FLORENCE L. IZZARD ( $H$. T.-Graceful, urn-like buds of deepest yellow, opening to large, high centered flowers of good substance and fine fragrance. Free flowering plant with good foliage.

JULIEN POTIN (H. T.) - A profuse blooming plant bearing deep yellow pointed buds, opening to primrose yellow flowers of good form. A promising new yellow, called by some, "Golden Pernet". 
LADY MARGARET STEWART-A marvelous recent introduction, which was awarded the Gold Medal of the National Rose Society of England. The quite unique color is deep sunflower yellow, heavily veined and splashed with orange scarlet. These colors intermingle as the flower develops into a beautiful orange effect. Flowers are quite pointed and sweetly scented.

MISS C. E. VAN ROSSEM (H. T.)-Velvety, dark red, well formed buds and open flowers of nearly the same shade, reinforced with scarlet and black. Strong free-flowering plant...

MRS. BEATTY (Pern.) - Superb buds of sulphur yellow, holding its color in a good, open flower of semi-double form. Good foliage..

MRS. A. R. BARRACLOUGH (H. T.)-Beautiful soft pink buds opening into extremely large pink flowers, shaded with clear canary yellow at base of petals. Lovely formed flower of unusual fragrance.

MRS. HENRY BOWLES (H. T.) - A brilliant rose of piercing pink, shaded with orange salmon. Buds of fine size opening to large flower of elegant form. A lovely rose.

MIRS. TRESHAM GILPEY (H. T.) - A superb new introduction from British growers. Color is bright coral rose-shaded salmon. Sweet perfume. Bud is long exhibition form.....

NORIIAN LAMBERT (H. T.) - One of the best McGredy introductions. Handsome, coppery orange buds and very large semi-double îlowers of exquisite form, golden yellow, edged with coppery crimson.

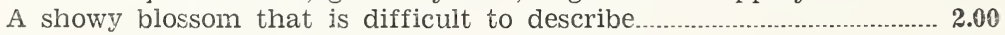

PINK PEARL ( $\mathrm{H}$. T.) A fine rose from Holland. Pink, as name indicates Massive buds and fragrant, well formed flowers borne on stiff stems $\mathbf{1 . 5 0}$

PRESIDENT CHERIOUX ( $\mathrm{H}$. T.) - Very large, salmon-pink blooms with reddish buff shading. Petals of lovely waxy texture. A choice plant of excellent habit.

SIR DAVID DAVIS ( $H$. T.) - Deep glowing crimson of very even shade, lightened with yellow at base of its large shell-like petals. High centered flower with long pointed bud. Delicious fragrance.

TALISMAN (Pern.) - A splendid new, American introduction. Long pointed buds, opening into well formed flowers in colors most difficult to describe, showing rich shades of golden yellow, coral pink, apricot and orange. Glossy green foliage of good substance.

WILHELMI KORDES (Pern.) - Long pointed buds and high centered flowers of polychrome tints, golden yellow at base, merging into capuline red with deep carmine veins... 


\section{Some Very New Ones}

These three have not yet bloomed with us but are introduced and guaranteed by one of the most careful and reliable concerns in America.

MARIE DOT (Pern.) - A Spanish rose of unique color and delightful perfume. "The pointed bud is deep apricot darkened with orange, opening to a double imbricated bloom of uniform apricot without shading, showing golden stamens or maroon filaments in the center"...

LI BURES (Pern)-We quote the introducer's description:

"In these days of modern art, a new expression has forced its way into rose parlance, 'Pictorial,' and we do not know of any rose to which this adjective can be better applied than Li Bures. We might aIso call it Kaleidoscopic, because of its variety of tints, transmitted in mingled fashion by its progenitors, Chateau de Clos Vougeot and Souv. de Claudius Pernet. The bud first shows maroon, gradually lightened with orange and yellow as the flower expands. As a moving panorama, these tints blend into new ones until toward the end, when the outer petals assume a velvety purple-crimson, while the center becomes old-rose suffused with yellow. Distinctly fragrant. The plant is vigorous, upright and bushy with strong, hollylike, disease-resistant foliage".

MME. GREGOIRE STAECHELIN (Cl. H. P.)-

"When the jury composed of celebrities from nine countries of the rose world, including the United States, met on June 11, 1927, to make the awards of the year at the famous international testing gardens of Bagatelle, Paris, they unanimously suspended the rules by which only a Certificate of Merit can be awarded a climber and granted Mme. Gregoire Staechelin the supreme honor of Rosedom, 'The Gold Medal of Bagatelle.' Such a distinction may not happen again in our lifetime!"

When the sepals of the long-pointed buds begin to divide, the first color is a deep maroon, which will leave an indelible imprint to the last, but as the bud develops into the rare and graceful urn-shape, that maroon stripe begins to run into a graduated carmine, paling some as the bloom expands into a large semi-double cup, each flower radiating a delightful fragrance of its own.

The buds come three to five on the stems, opening one after the other, giving an unusually long season. Were the side buds removed, the terminal ones would grow into mammoth blooms. These blooms are borne on 12 to 15 inch stems.

The plant is extremely vigorous, growing easily 12 feet or more, each year climbing higher. The foliage is beautiful olive color, ample and leathery. A most useful and effective perfectly hardy cllimbing rose." 


\section{General List of Good Roses}

Of these, some are of recent introduction, others are proven favorites. All are field grown two-year-old plants of first quality.

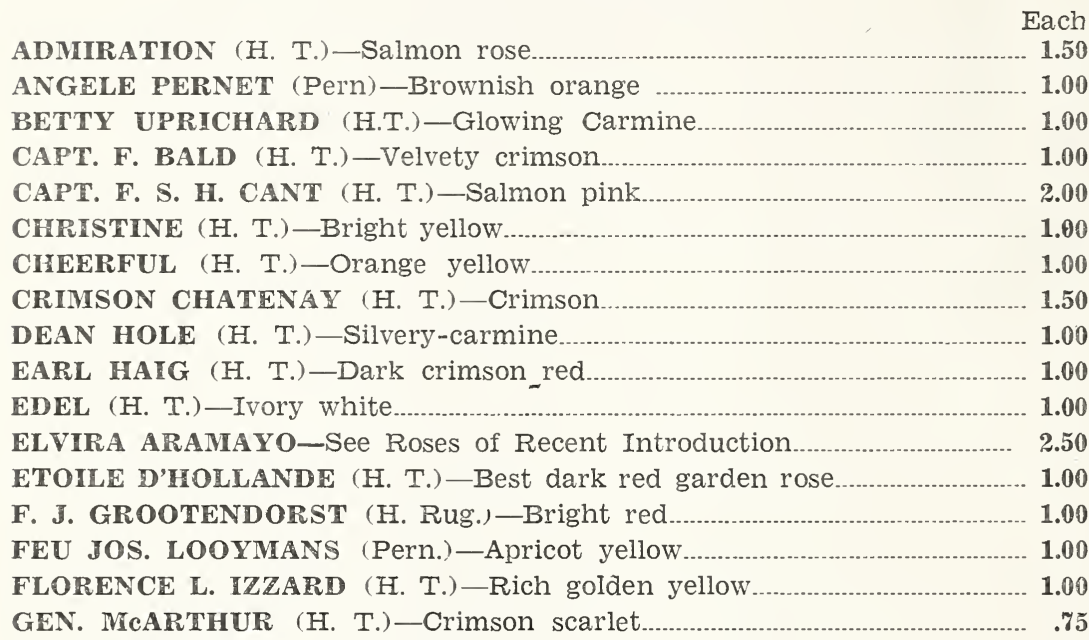

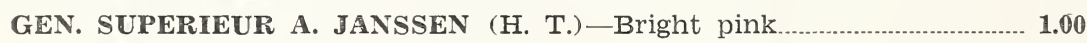

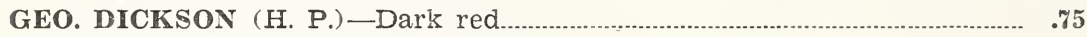

GEO. C. WAUD (H. T.) - Light red. 1.00

GLENN DALE (H. W.) - Lemon pillar

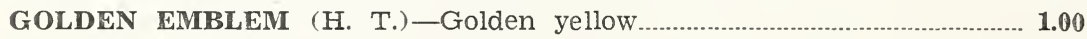

GORGEOUS (H. T.) -Golden copper

GWYNETH JONES (Pern.) - Carmine orange

GWYNNE CARR (H. T.) -Shell pink. Fragrant............................................. 1.50

HADLEX (H. T.) —Crimson red

HAWLMARK CRIMSON ( $\mathrm{H}$. Bengal) -Deep, almost maroon_....................... 1.00

INDEPENDENCE DAY (H. T).-Brownish yellow.................................... 1.00

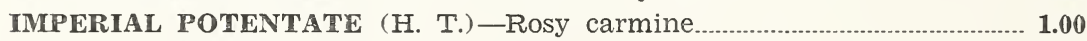

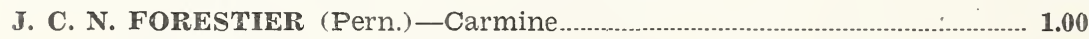

J. G. GLASSFORD (H. P.) - Bright crimson 1.00

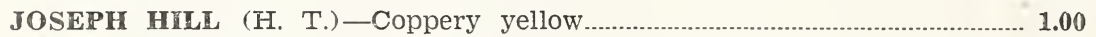

J. J. L. MOCK (H. T.) - Imperial pink

J. B. CLARKE (H. P.) -Deep scarlet

JUNE BOYD (H. T.) —Salmon carmine............................................................. 1.00

KILLARNEY WHITE (H. T.) —White, long bud ….................................. .75

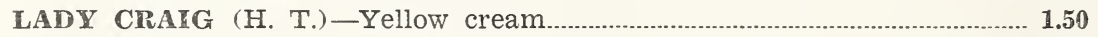

LADY HILLINGDON (T.) - Rich, ochre yellow................................................. 1.00

LADY PIRRIE (H. T.) - Coppery salmon ................................................. 1.00

LADY ROUNDWAY (Pern.) - See Roses of Recent Introduction.

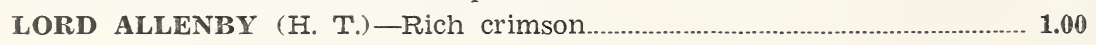


Each

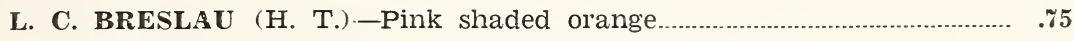

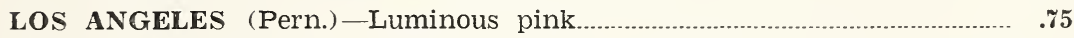

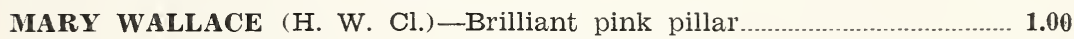

MME. BUTTERFL (H. T.) —Pink, cream, gold

MME. EDOUARD HERRIOT (Pern.)-Coral red-orange ..............................75

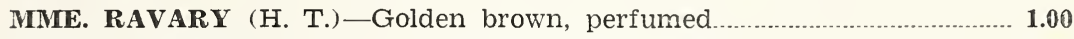

MAMA LAMESCH ( $\mathrm{H}$. T.) - Glowing salmon pink

MRGT. DICKSON HAMMILL (H. T.)-Delicate straw .....................................

MISS C. E. VAN ROSSEM (H. T.)-See Roses of Recent Introduction.

MISS WILLMOTT (H. T.)-White, tinted pink

MRS. AMBROSE RICCARDO ( $\mathrm{H}$. T.) -Yellow, tinged pink .................... 1.00

MRS. CALVIN COOLIDGE (H. T.)-Clear, buff-yellow ................................. 1.00

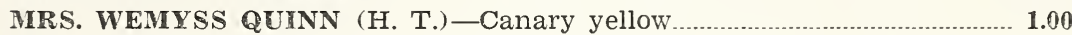

MRS. HENRY BOWLES (H. T.)-Clear, piercing pink ............................. 1.50

MRS. HENRY MORSE (H. T.)-Two-tone pink

MRS. H. R. DARLINGTON (H. T.)-Large creamy white

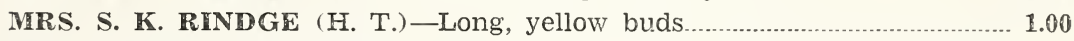

MRS. TALBOT O'FARRELL (H. T.) - See Roses of Recent Introduction.

MRS. W. C. EGAN (H. T.) — Silvery shaded pink ..................................... 1.00

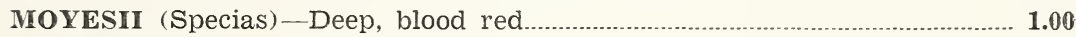

MODESTY (H. T.)-White and cream

NORMAN LAMBERT (H. T.) - See Roses of Recent Introduction.

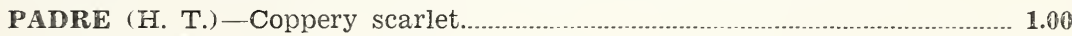

PINK PEARL (H. T.)-See Roses of Recent Introduction.

PHARISAER (H. T.) - Rose pink and salmon

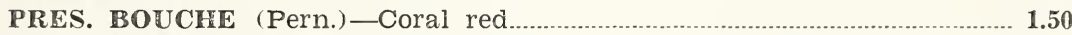

PRES. CHERIOUX (H. T.) - See Roses of Recent Introduction.

PRES. WILSON (H. T.)-See Roses of Recent Introduction.

RADIANCE-(H. T.)-Pink.

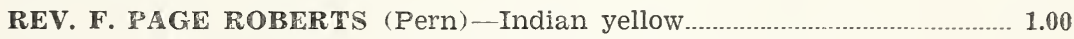

SALMON SPRAY (Poly.) - See Roses of Recent Introduction.

SCARLET GLORY (H. T.) - See Roses of Recent Introduction.

SHOT SILIK (H. T.)-Coppery rose.

SIR DAVID DAVIS (H. T.) - See Roses of Recent Introduction.

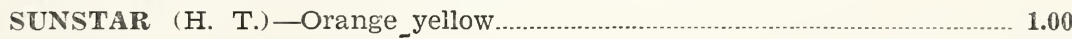

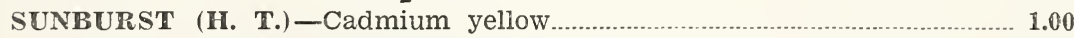

SOUV. DE CLAUDIUS PERNET (Pern.)-Golden yellow............................. 1.00

SOUV. DE GEORGES PERNET (Pern.) - Oriental red.............................. 1.00

SOUV. DE H. V. VERSCHUREN (H. T.)-Cadmium to orange.........................

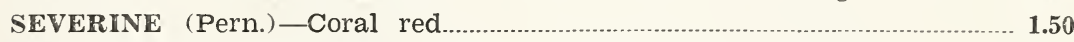

THE QUEEN ALEXANDRA (Pern.)-Vermillion and old gold.................. 1.00

VICTOR WADDILOVE (H. T.)-Carmine pink

WHITE ENSIGN (H. T.) -See Roses of Recent Introduction.

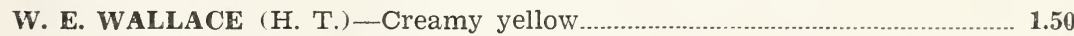

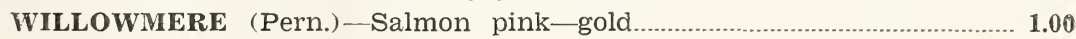




\section{Hardy Climbing Roses}

By the term "Climbing Roses," is meant the several types which have a different habit from the dwarf or "bush" roses. Climbers have many uses and in selecting a desired plant, the particular use for which it is intended should be considered. Is it to cover a fence, or garage, or even a house? Is it to hide something, or is it to be confined to a single column of green leaves and bright blossoms against the side of a light colored stucco house? Or, perhaps, its landscape effect should be a pillar eight or ten feet high to relieve the monotony of evenly growing things. Perhaps to mark a boundary, or even to hold a bank, or cover a bare spot, grown as trailers on the ground.

We have these Climbers, Ramblers, Pillars and Ground Covers in most all the worthy varieties and, with the exception of novelties, the price is $\$ 1.00$ for strong, two-year-old, field-grown plants.

We shall be glad to advise customers on their particular requirements.

\section{Rose Shrubs}

Some roses are particularly useful as flowering shrubs. Either as individual specimens on the lawn, or to give to the border bright flowers in the summer, or brilliant berries in the winter.

We have these shrubby roses in variety, at $\$ 1.00$ each.

\section{Select List of Hardy Varieties}

We are frequently asked for roses that will endure the harsh winters of Canada and the northern tier of our states. The ever-blooming Hybrid Teas and Hybrid Perpetuals are grown under conditions prevailing in those localities, but require much winter protection which, while worth while, may not be convenient.

The following varieties, however, will stand the winters allmost anywhere in northern United States and Canada with little or no protection:

The D. P.'s, or dwarf polyanthas, are dwarf growing and are most suitable for massing in beds or borders. Harrison's Yellow, Persian Yellow, and Star of Persia are hybrid Austrian Briars, and are tall-growing and flower on the twoyear-old wood. They are well suited for specimen planting or as windbreaks for the more tender occupants of the rose garden. The Rugosa hybrids, such as Hansa, F. J. Grootendorst, Sir Thomas Lipton, are fairly tall-growing, and are well suited for planting in groups in beds or as low hedges. Other hardy roses are described individually.

Each

ALICE AMOS, D. P. (Jan Spek, 1922)-Large, single flowers of bright cherry red with white center, borne in immense clusters throughout the whole summer and fall 
AUSTRIAN COPPER, H. A. B. (Gerarde, 1596)-Single flowers of intense coppery red, reverse of petals, bright golden yellow. Very hardy and vigorous

BENEDICT ROEZL, H. R.--Large full blooms of delicate carmine pink, sweetly scented. This is probably the best amongst the rugosa hybrids, possessing flowers of hybrid tea type with the hardy, rugged growth of the rugosa

BLANCHE MOREAU, Moss (Moreau-Robert, 1880)-Double white flowers heavily mossed, vigorous and hardy.

CONRAD FERDINAND MEYER, H. R. (Muller, 1900)-Very large, well built flowers of silvery pink, produced on great thorny canes of enormous height. A fine, hardy pillar rose.

CRESTED MOSS, Syn. Chapeau de Napoleon (Found in Friburg, Switzerland, 1827)-Large, full flowers of bright rose pink, beautifully mossed

EBELOUISSANT, D. P. (E. Turbat \& Co., 1918)-Glowing, dark red flowers quilled like little cactus dahlias, shaded heavily with velvety crimson. Dwarf, robust plant

EDITH CAVELL, D. P. (Meiderwyk, 1917-Small, semi_double flowers of bright scarlet red, produced in great trusses.

F. J. GROOTENDORST, H. R. (DeGoey, 1918)-Small fringed flowers of bright red, aptly called "the carnation rose." The flowers are produced in great clusters on sturdy growing plants with very ornamental foliage

HANSA, H. R. (Schaum, 1905) -Double reddish violet flowers of large size. Plant robust and hardy

HARRISON'S YELLOW, H. A. B. (Harrison, 1930)-Semi-double flowers of pale yellow, covering the big bushes early in the season. Vigorous and hardy

READING, D. P. (Vanherk, 1921) - Bright red flowers in large clusters, individual flowers large and slightly fragrant.

MAX GRAFF, H. R. (Bowditch, 1919)-Large single flowers of shining pink, freely produced in its season. This is a rose which may be favorably used as a climber in the colder sections of Canada, as a cover for banks or rockeries. It is very beautiful when in bloom, and, as its foliage is very ornamental, it should not be overlooked for the same kind of use in the more favored parts of th ecountry....

ORLEANS, D. P. (Levavasseur \& Sons, 1910)-Flowers small, semi-double, bright red with white eye. Blooms the whole season through.

PERSIAN YELLOW, H. A. B. (Willock, 1837)-Double yellow flowers of
deep golden yellow (produced along the stems of the previous year's

PERSIAN YELLOW, H. A. B. (Willock, 1837)-Double yellow flowers of
deep golden yellow (produced along the stems of the previous year's growth. Hardy

RODHATTE, D. P. (D. F. Poulsen, 1922)-Large, semi-double flowers of shining crimson produced in great clusters and flowering right up

to severe frost. One of the best of this class.................................
ROSA, $\mathbf{H}$. R. (Raised at the Central Experimental Farm. Ottawa,

RUBROSA, H. R. (Raised at the Central Experimental Farm. Ottawa, Ont.) - As the name suggests, this is a cross between rosa rubifolia and rosa rugosa. This is a very ornamental, strong growing shrub, with reddish foliage and stems, the latter showing up well against the snow in winter. The flowers are pink, fairly abundantly produced $\mathbf{1 . 5 0}$

SCHNEEZWERG, H. R. (P. Lambert, 1912)-Semi-double, snow-white flowers showing golden stamens. A small, spiny shrub with very ornamental rugose foliage. Very hardy. 
Printed By

MILLER \& SUTHERLEN PRINTING CO., Bellingham, Washington 
This Page for Your Memorandum of Plants You Intend to Order 


